\title{
KOLIKO SE (NE)POZNAJEMO \\ TOLIKO SMO TOLERANTNI? \\ MUSLIMANKE I MUSLIMANI O SEBI I DRUGIMA U BOSNI I HERCEGOVINI
}

\section{Sažetak}

U ovom radu analiziramo koliko studentice i studenti koji se deklariraju kao muslimanke i muslimani poznaju sebe i svoju religijsku tradiciju, koliko prakticiraju islam, ali i koliko poznaju druge religijske tradicije u svom okruženju te kakve stavove imaju o svojim komšijama katolicima, pravoslavnim, jevrejima i onima koji se izjašnjavaju kao ateisti i agnostici. Građani Bosne i Hercegovine uglavnom žive u etnički i religijski podijeljenim i homogenim sredinama i mladi se socijaliziraju i obrazuju u takvom okruženju, uz religijsko konfesionalno obrazovanje koje pohađa većina djece. Sociološko istraživanje pod nazivom "Koliko se poznajemo" ima za cilj pokazati da li u kojoj mjeri nepoznavanje vlastite a posebno religije/ konfesije drugoga doprinosi socijalnog distanci, te da li je to prepreka dijalogu i izgradnji kulture mira. Stupanj religioznosti mladih je analiziran kroz ideološku, obrednu i intelektualnu dimenziju, kako bi se utvrdilo koja je razina religijske pismenosti. Rezultati istraživanja pokazuju koje vrste autostereotipa muslimanke i muslimani imaju o sebi, uglavnom pozitivnih, u odnosu na druge, ali i koje vrste heterostereotipa imaju prema svojim komšijama. U konačnici, koliko muslimani kao najbrojniji u $\mathrm{BiH}$ (50,7 procenata ukupne populacije) pokazuju socijalnu distancu prema svojim komšijama jevrejima, katolicima i pravoslavnim, ali nereligioznim osobama, i koliko to utječe na njihovu opredijeljenost za prihvaćanje različitosti, a ne samo pasivnu toleranciju?

Ključne riječi: studenti, muslimani, religioznost, socijalna distanca, autostereotipi, heterostereotipi, kultura mira 


\section{Uvod}

"Ovdje su narodi i ljudi uvijek živjeli zajedno, slavili praznike i poštovali jedni druge."

Ovo je rečenica koju često možemo čuti u Bosni i Hercegovini (BiH) kada god se pokrene rasprava o suživotu, pomirenju, kulturološkim i religijskim razlikama. Iako je ova rečenica tačna, da su ljudi stoljećima živjeli zajedno i preživljavali burne povijesne trenutke kada god su imperije sa Istoka i Zapada, ali i susjedne države ostvarivale svoje političke planove, to samo po sebi ne znači da se oni i poznaju. Naučili su muslimani, katolici, pravoslavni i jevreji kako opstati, a onda i kako živjeti zajedno, nekada jedni sa drugima, a nekada jedni pored drugih unatoč čestim ratovima i razaranjima i etno-nacionalnim podjelama koje su posebno izražene danas nakon rata (1992-1995).

U BiH, ali i cijeloj Jugoistočnoj Evropi već stoljećima žive zajedno jevreji, kršćani i muslimani i kako Michael Mitteaur ističe, nijedan drugi dio Evrope nije na takav način obilježen supostojanjem različitih religija sa specifičnom religijskom topografijom $(2008,8)$. Možemo još dodati i to da su religijske tradicije judaizma, kršćanstva i islama uveliko utjecale jedna na drugu kroz višestoljetno prožimanje i razmjenu kulturnih i običajnih praksi, a tome je pogodovalo i to što unatoč kulturnim i religijskim posebnostima ljudi na ovim prostorima imaju zajednički jezik: bosanski, hrvatski i srpski (BHS).

Poštovanje o kojem se govori nužno ne mora značiti i da ljudi doista poznaju kako svoju tako i druge religijske tradicije i kulture, a isto tako da je poznavanje drugoga i njegove/njene tradicije i kulture garant tolerancije i uvažavanja. Na koncu zadnji rat je pokazao da su komšije bile najžešći neprijatelji svojim komšijama sa kojima su se družili, obilježavali blagdane, prihvaćali kumstva, prijateljske i bračne veze. Čestitati nekome vjerski praznik, proslaviti zajedno Bajram, Božić ili Pesah, ne znači poznavanje porijekla, svrhe i značenja takvih religijskih praksi i to nije garant uvažavanja drugoga. Pored znanja i upoznavanja, važno je kultivirati empatiju i interkulturalne i međureligijske kompetencije od najranije dobi, kako bi se razvio odnos pun uvažavanja i razumijevanja te kako bi osoba mogla iskoračiti iz monokulturne u etnorelativnu perspektivu (Bennett, 1986).

Kognitivne razvojne teorije koju su još sredinom 20. stoljeća ponudili Jean Piaget i Anne Marie Weil (1995:248-75), a kasnije i Frances Aboud (1988, 24-25) pokazuju da kada dijete usvaja društvene kategorije i norme ponašanja ono neminovno naglašava razlike među društvenim grupama, doživljavajući 
vlastitu grupu vrednijom. Stupanj tolerancije i uvažavanja će se povećavati u periodu odrastanja kada se smanjuje interes za društveno kategoriziranje. Da bi osoba razvila političke stavove aktivne tolerancije i uvažavanja potrebno je da kultivira nenasilje i izbjegavanje kršenja prava drugih koji su etnički, religijski, rasno, klasno ili rodno drugačiji.

U toku primarne i sekundarne socijalizacije važno je da mlada osoba razvija društvene i emocionalne vještine koje joj mogu pomoći da ostvari uspješnu interakciju sa vršnjacima, a kasnije i sa drugim ljudima (Piaget i Weil 1995:248-75). Na ovaj način se uči kako iz pozicije sebične i egoistične osobe prerasti u osobu koja je spremna da pregovara i kolaborativno rješava sve izazove i probleme s kojima se susreće. Ove vještine su posebno važne kada se osoba susreće sa drugima koji imaju, ne samo različite identitete već i suprotstavljena ideološka i druga polazišta i ciljeve.

Pitanje je kako se djeca i mladi u BiH socijaliziraju, da li se uče toleranciji i uvažavanju ili u monokulturnim zajednicama u kojima većina odrasta nakon rata, nemaju priliku učiti o drugima, ili učiti o drugima bez stereotipa i predrasuda koje su integralni dio kultura na ovim prostorima - posebno su upečatljivi etnički, religijski i rodni stereotipi i predrasude? Mnogo toga se podrazumijeva i pretpostavlja, pa se danas misli da s obzirom da je vjeronauka dio obrazovnog sistema, građani $\mathrm{BiH}$ bi trebali mnogo više znati o svojoj i religijama svojih komšija i shodne tome biti tolerantniji. Međutim, kako Adila Pašalić Kreso navodi:

Tipičan bosanskohercegovački učenik školovanjem u okviru nacionalnog kurikuluma usvaja isključivo vrijednosti svoje kulture, religije, historije, specifičnosti jezika čime mu se stvara utisak da ta kultura predstavlja nadogradnju kulture ili natkulturu njegove etničke mikrozajednice u kojoj živi i odrasta. $(2016,19)$

Stoga je važno pitanje da li se i kako učimo o drugima? Kroz istraživanje pod nazivom "Koliko se poznajemo", provedeno među studentima i studenticama na državnim univerzitetima $\mathrm{u} \mathrm{BiH}$, vidljivo je da mladi ne samo da ne poznaju dovoljno religiju i tradiciju svojih komšija, nego nisu dovoljno upoznati ni sa vlastitom religijskom tradicijom, osim što imaju elementarna znanja o tome.

\section{Uzorak i cilj}

Sociološko istraživanje pod nazivom "Koliko se poznajemo" provelo je Odjeljenje društvenih nauka ANUBiH na uzorku od 499 studentica i studenata sa osam državnih univerziteta iz sedam gradova u BiH: Sarajevo, B. 
Luka, Istočno Sarajevo, Mostar, Zenica, Tuzla i Bihać, uključujući i studentice i studente četiri teološka fakulteta: Fakultet islamskih nauka, Katolički bogoslovni fakultet i Franjevački teološki fakultet iz Sarajeva, te Bogoslovija Svetog Petra Dabrobosanskog u Foči. Cilj je bio ispitati u kojoj mjeri nepoznavanje vlastite, a posebno religije/konfesije drugoga među studentima, doprinosi socijalnoj distanci, te da li je to prepreka dijalogu i izgradnji kulture mira. Rezultati istraživanja su potvrdili postavljenu hipotezu da što mladi manje znaju o sebi i drugima i svom okruženju, to će biti udaljeniji jedni od drugih što će konsekventno utjecati na izgradnju kulture mira.

U ovom dijelu analize, izdvajamo odgovore studentica i studenata koji se deklariraju kao muslimanke i muslimani i donosimo podatke o tome koliko poznaju islam, i islamsku tradiciju ali i religijske tradicije svojih komšija: pravoslavaca, katolika i jevreja, te kako percipiraju druge koji se ne deklariraju kao vjernice i vjernici ili kao pripadnici četiri dominantne konfesije.

Omjer muslimanki i muslimana u uzorku reflektira omjer u ukupnom broju stanovnika sa zadnjeg popisa stanovništva iz 2013. godine, prema kojem se 96,6 procenata građanki i građana $\mathrm{BiH}$ deklariralo kao vjernice i vjernici, a od toga 50,7 procenta se izjasnilo kao muslimanke i muslimani. Svi ispitanici koji su se deklarirali kao muslimanke i muslimani su se također deklarirali Bošnjakinje i Bošnjaci. To je također pokazatelj izjednačavanja etničkog i religijskog identiteta, što je posljedica složenih povijesnih događanja u kojima su Bošnjaci koristili dvostruku dezignaciju (Imamović, 2003, 327).

Zanimljivo je i to da je veći broj žena učestvovao u istraživanju $(47,8$ procenata žena i 29,9 procenata muškaraca, ostali se nisu izjasnili), što također odgovara većem broju studentica na društvenim i humanističkim fakultetima u odnosu na muškarce.

\section{Ko sam ja i koliko poznajem svoju religijsku tradiciju?}

Prethodna istraživanja provedena u BiH (Spahić Šiljak, 2007; Puhalo, 2009; Abazović, 2012; Majstorović i Turjačanin, 2013; Pehlić, 2019) pokazuju da je religija zajedno sa etničkim/nacionalnim identitetom ključan element identifikacije za većinu građana $\mathrm{BiH}$. Šta to onda znači biti muslimanka ili musliman u BiH? Koje su to važne odrednice muslimanskog identiteta i na koji način se one reflektiraju na ličnoj i kolektivnoj ravni?

Kada govorimo o identitetima, onda govorimo o kompleksnom fenomenu pripadanja, prije svega porodici, religijskoj i etničkoj zajednici, regiji, zemlji, ili nekoj drugoj mnogo široj formi, kao što je primjerice ummet (duhovna 
zajednica) za muslimane. U nastojanju da se odgovori na pitanje osobnog identiteta, većina ljudi govori o svojim ulogama koje se ne biraju (porodične uloge: kćerka, sin, sestra...) ili ulogama koje biraju poput obrazovanja i posla kojim se bave, a uz sve to dolazi i pripadanje naciji i religiji. Antropološka studija Tone Bringa Biti musliman na bosanski način (1995, 174-176) pokazala je da su $\mathrm{BiH}$ muslimani prije rata bili prilično sekularizirani, iako je $\mathrm{i}$ tada bio visok stupanj identifikacije sa religijom. Kasnija istraživanja također pokazuju značajniji stupanj identifikacije sa religijom. U knjizi Žene, religija i politika (Spahić Šiljak, 2007, 2020) vidljivo je kako je religijska identifikacija muslimana, pravoslavaca i katolika 91,11 procenata. Nakon toga u istraživanju objavljenom pod nazivom Bosanskohercegovački muslimani između sekularizacije i desekularizacije (Abazović, 2012, 125-130) u kojoj su učestvovali samo muslimani, religijska identifikacija je bila 82,6 procenta, ali samo 18,4 procenata ispitanika obavlja pet dnevnih molitvi (namaz), a 13,3 manje od pet dnevnih molitvi. Istraživanje koje je objavljeno u istom periodu sa građanima različitih etničkih i nacionalnih opredjeljenja pod nazivom Youth Ethnic and National Identity in Bosnia and Herzegovina (Etnički i nacionalni identitet mladih u Bosni i Hercegovini, (Majstorović i Turjačanin, 2013, 102-103) također je pokazalo vrlo visok stupanj religijske identifikacije muslimana koja se procentualno poklapa sa nacionalnim identitetom Bošnjak: 95,6 procenata. Xavier Bougarel proces izjednačavanja religijskog i nacionalnog identiteta karakaterizira kao reislamiziranje Bošnjaka i nacionaliziranje Islama $(2017,158)$, i to potvrđuje izjavama muslimanskih intelektualca koji su bili javno i politički angažirani 1990-ih na pitanjima profiliranja Bošnjaka i njihovog nacionalnog identiteta.

Odgovori studentica i studenata muslimanki i muslimana u ovom istraživanju pokazuju na koji način oni doživljavaju svoj društveni religijski identitet koji je omeđen kontekstom u kojem žive, ali i pripadnošću porodici u kojoj se manje ili više prakticira religija, odnosno u kojoj je manje ili više izražen religijski identitet. S obzirom da religija, ali i nacija imaju integrativnu moć da osobi daju sigurnost i stabilan okvir, onda ne čudi da se veliki broj ljudi u post-ratnom kontekstu bremenitom brojnim ekonomskim i političkim problemima, uključujući i probleme negiranja identiteta, jezika i kulturološke posebnosti, identificira sa religijom i nacijom i da se nacionalno i religijsko uglavnom preklapaju, jer je na ovim prostorima religijska pripadnost ključni element nacionalnog identiteta.

Rezultati ovog istraživanja pokazuju da je religijska identifikacija muslimanki i muslimana vrlo visoka: 94,8 procenata, da se 93,2 procenta njih izja- 
snilo kao Bošnjakinje i Bošnjaci, a 90,4 procenata da im je maternji jezik bosanski. Nekoliko pitanja je bilo usmjereno na to da se ustanovi u kojoj mjeri su muslimanke i muslimani vezani za svoju naciju, religiju, jezik i zemlju, što je jedan od pokazatelja njihove otvorenosti prema drugima. Iako se veliki broj muslimanki i muslimana izjasnio nacionalno kao Bošnjakinje i Bošnjaci, njihov odnos prema tom identitetu je u nešto manjem procentu izrazito važan.

Tabela 1 .

\begin{tabular}{lll}
\hline Moj odnos prema nacionalnoj pripadnosti & Musliman & Muslimanka \\
\hline prihvaćam svoju nacionalnu pripadnost, ali ne mislim puno o njoj & $36,7 \%$ & $42,3 \%$ \\
\hline moja nacionalna pripadnost za mene nije važna & $6,3 \%$ & $9,5 \%$ \\
\hline nacionalna pripadnost je važan dio mog života & $34,8 \%$ & $26,9 \%$ \\
\hline ne znam & $17,7 \%$ & $20,2 \%$ \\
\hline
\end{tabular}

Slično kao i sa prethodnim pitanjem, veliki broj ispitanika se deklarirao kao muslimanke i muslimani, ali im je važnost religijskog identiteta procentualno manja od formalnog pripadanja.

Tabela 2.

\begin{tabular}{lll}
\hline Važno mi je što sam pripadnik/ca svoje religije & Musliman & Muslimanka \\
\hline veoma mi je važno & $62,0 \%$ & $64,2 \%$ \\
\hline djelomično mi je važno & $15,8 \%$ & $13,5 \%$ \\
\hline niti mi je važno nit nevažno & $5,1 \%$ & $7,8 \%$ \\
\hline uopće mi nije važno & $6,3 \%$ & $6,7 \%$ \\
\hline ne znam & $6,3 \%$ & $6,3 \%$ \\
\hline
\end{tabular}

Zanimljivo je također da više od polovice ispitanih doživljava kritiku upućenu muslimanima kao ličnu kritiku, što je pokazatelj emocionalne vezanosti za religiju i važnosti kolektivnog religijskog identiteta i pripadanja zajednici. Prema Teoriji samokategorizacije (Turner et. al. 1994) kada pojedinac doživljava sebe manje kao individuu, a više kao pripadnika grupe onda se u procesu depersonalizacije povećaju autostereotipi. To ne znači da on gubi svoju osobnost, već je redefinira u skladu sa osjećajem pripadnosti određenoj grupi. Zbog toga se i kritika upućena grupi kojoj osoba pripada doživljava lično. 
Tabela 3.

\begin{tabular}{lll}
\hline Kada neko ko nije pripadnik moje religije kritizira muslimane & Musliman & Muslimanka \\
\hline to doživljavam kao ličnu/osobnu kritiku & $24,1 \%$ & $23,8 \%$ \\
\hline to djelimično doživljavam kao ličnu/osobnu kritiku & $28,5 \%$ & $38,1 \%$ \\
\hline to uopće ne doživljavam kao ličnu/osobnu kritiku & $35,4 \%$ & $25,8 \%$ \\
\hline ne znam/bez odgovora & $9,5 \%$ & $10,0 \%$ \\
\hline
\end{tabular}

Sociolozi religije (Glock i Stark, 1965, cit. u Abazović, 2012, 125-126, Cvitković, 2007, 93-109) su religioznost kao multidimenzionalni fenomen mjerili preko pet dimenzija religioznosti: a) vjerovanje (ideološka dimenzija - privrženost vjerovanju), b) prakticiranje religije (obredna dimenzija-koliko često neko obavlja molitve i druge obrede), c) osjećaji (iskustvena dimenzija - koliko se emocionalno povezuje sa transcendentnim, d) efekti (posljedična dimenzija - kako vjera i praksa utječe na život vjernice i vjernika), f) znanje (intelektualna dimenzija - stupanj poznavanja normi i propisa vjere).

Međutim, pored ovih dimenzija religioznosti važno je imati u vidu i odnos crkve i vjerske zajednice sa državom, odnosno da li je ta zajednica u povlaštenom položaju, i da li država favorizira religijski svjetonazor, što se dogodilo na Balkanu 1990-ih (Kuburić i Kuburić Borović, 2009, 48). Tome možemo dodati još i to da li su određene crkve i vjerske zajednice zakonom u povlaštenijem položaju, kao što su to Katolička i Pravoslavna crkva, te Jevrejska i Islamska zajednica, jer su Zakonom definirane kao tradicionalne zajednice $u$ odnose na druge manjinske zajednice. ${ }^{57}$

U ovoj analizi ćemo koristiti samo tri dimenzije religioznosti: ideološku, obrednu i intelektualnu, jer istraživački materijal nije dostatan da se posebno analiziraju iskustvena i posljedična dimenzija religioznosti.

\subsection{Ideološka dimenzija}

Pitanja u ovom dijelu istraživanja koncipirana su tako da pokažu osnovne postulate vjerovanja $u$ islamskoj tradiciji koji se, između ostalog, temelje na: 1. vjeri u jednog Boga (Allah), 2. postojanju duhovnih svjetova (šejtani i džini), 3. vjeri u eshatologiju: 4. proživljenje na budućem svijetu (ahiret), 5. odgovornost za grijehe, 6. vjerovanje u džennet (raj) i džehennem (pakao).

\footnotetext{
${ }^{57}$ Zakon o slobodi vjere i pravnom položaju crkava i vjerskih zajednica u Bosni i Hercegovini ("Službeni glasnik BiH", broj 5/04). Ovaj zakon u članu 8. regulira da kontinuitet pravne osobe historijski zasnovanim crkvama i vjerskim zajednicama: Islamskoj zajednici, Srpskoj pravoslavnoj crkvi, Katoličkoj crkvi i Jevrejskoj zajednici, kao i svim ostalim crkvama i vjerskim zajednicama kojima je priznato svojstvo pravne osobe prije stupanja na snagu ovog zakona. U članu 18 se dalje utvrđuje da nove religijske zajednice trebaju 300 potpisa svojih članova da bi registrirale crkvu ili vjersku zajednicu.
} 
Kada se pogleda broj onih koji su naveli da vjeruju u jednog Boga, 97,6 procenata, onda je vidljiva razlika u odnosu na one koji su se izjasnili kao muslimanke i muslimani, 94,8 procenta. Iako je ovo procentualno mala razlika, ipak je pokazatelj da ima onih koji vjeruju u Boga, ali se ne izjašnjavaju kao muslimani. To je onaj dio vjernica i vjernika koji svoju duhovnost i vjeru ne vezuju uz određenu religiju i religijsku zajednicu, već okvir svoje duhovnosti traže izvan zadatih identiteta i pripadnosti, što je britanska sociologinja Grace Davie nazvala "vjerovanjem bez pripadanja" (1994). U odnosu na stanje u zapadnoeuropskim zemljama gdje je uveliko prisutna individualizacija i privatizacija religije (Pippa i Inglehart 2011) BiH cijeli region Balkana imaju vrlo visoku razinu religijske identifikacije i pripadanja crkvi i religijskoj zajednici (Flere, 2007).

Manji broj ispitanika, 14,3 procenta nije povezao svoje vjerovanje u Boga sa pripadnošću Islamskoj zajednici iako su se deklarirali kao muslimanke i muslimani. Ne smatraju organizirani institucionalizirani oblik religioznosti kompatibilnim sa njihovom osobnim poimanjem Boga. Velika većina 43,4 procenta ipak religijske zajednice vidi kao prostor za ispoljavanje vlastite religioznosti, bez kritičkog osvrta, dok 10,8 procenata unatoč kritici i političkim zloupotrebama religijsku zajednicu ipak doživljavaju kao izvor smisla i društvenih vrednota. Ovako visoka razina povjerenja u instituciju podsjeća na ono što Grace Davie $(2012,169)$ naziva "vikarna" odnosno "zastupnička religija" - aktivna manjina djeluje u ime neaktivne većine koja odobrava njene postupke, u ovom slučaju predstavljanje svoje religijske zajednice. Iako muslimani u formalnom smislu nisu manjina, ipak mali broj je aktivan u Islamskoj zajednici i kroz obrede i druge aktivnosti, što će se kasnije pokazati u analizi. Dakle, iako je religijska identifikacija vrlo visoka, prakticiranje religije i odlazak u džamiju je vrlo nisko: 19,9 procenata odlaze u džamiju jednom sedmično, iako muslimani imaju pet dnevnih molitvi.

Druge karakteristike osobne vjere su u velikom procentu zastupljene kod ispitanica i ispitanika.

Tako, naprimjer, 79,7 procenta vjeruje u postojanje duše, dok samo 6,4 procenta nisu sigurni u to. Ipak 83,7 procenata ispitanih vjeruju u postojanje grijeha, 88,8 procenta vjeruje u postojanje dženneta (raj), a 87,3 procenta $u$ postojanje džehennema (pakao), dok 9,6 procenata ne vjeruju, 75,3 vjeruje u postojanje šejtana (sotona). Zanimljivo je međutim, da iako 62,5 procenta ispitanih vjeruje u zagrobni život, samo 25,1 procent vjeruju u uskrsnuće odnosno ponovno proživljenje nakon smrti, 17,9 nije sigurno, dok je 33,1 procenat uopće ne vjeruje u to. 
Analiziraju odgovore, ovo se čini nekonzistentnim i u nastojanju da interpretiram ovaj podatak u skladu sa ostatkom odgovora, jedino rješenje koje se nameće je da za muslimanke i muslimane struktura pitanja nije bila u skladu sa uobičajenim pojmovnim određenjem života poslije smrti. Sam pojam uskrsnuće je kršćanski i muslimani neće reći da će uskrsnuti poslije smrti, već da će biti proživljeni. Ako u velikom procentu vjeruju u zagrobni život, postojanje raja i pakla, onda je za očekivati da vjeruju i da će biti proživljeni da budu u raju ili paklu u koji vjeruju. Možda je razlog tome i to što proživljenje doživljavaju i tjelesno, a ne samo duhovno - da duša ide u raj ili pakao. Ovo je pokazatelj koliko je potrebno senzibilnosti u načinu kreiranja pitanja kako bi bila prilagođena grupama kojima su upućena, kako bi se dobila potpunija slika pitanja koje se istražuje. Pored toga, kako su ispitanice i ispitanici razumjeli pitanje, možda je na njihov odgovor utjecalo i to na koji način muslimanke i muslimani doživljavaju općenito slike života poslije smrti, da li više simbolički ili doslovno, jer vjerovanje da nešto postoji nužno ne mora biti praćeno i konkretnom slikom ostvarenja iste.

Ako navedene podatke razvrstamo po spolu, vidjet ćemo da postoje manje razlike između žena i muškaraca, ali ni u jednom pitanju te razlike ne prelaze 10 procenata. Zanimljivo da žene malo više vjeruju u postojanje dženeta (raja), a muškarci više vjeruju u proživljenje poslije smrti i postojanje džehenema (pakla).

Tabela 4.

\begin{tabular}{lll}
\hline Vjerovanje & Žene & Muškarci \\
\hline vjerujem u Boga & $90,4 \%$ & $83,5 \%$ \\
\hline vjerujem u postojanje duše & $85,2 \%$ & $80,1 \%$ \\
\hline vjerujem u postojanje dženeta (raj) & $74,5 \%$ & $66,5 \%$ \\
\hline vjerujem u postojanje džehenema (pakao) & $65,4 \%$ & $69,2 \%$ \\
\hline vjerujem u postojanje šejtana (sotona) & $58,1 \%$ & $63,8 \%$ \\
\hline vjerujem u zagrobni život & $53,5 \%$ & $57,0 \%$ \\
\hline vjerujem u uskrsnuće/proživljenje poslije smrti & $34,2 \%$ & $44,0 \%$ \\
\hline
\end{tabular}

Ovi podaci su slični rezultatima PEW istraživanja $(2016)^{58}$ u kojem su obuhvaćene 63 zemlje svijeta. Ne postoje značajnije razlike u vjerovanju

\footnotetext{
${ }^{58}$ Prema istraživanju koje provodi PEW Research, žene i muškarci podjednako vjeruju u postojanje raja pakla, i anđela i da su razlike u nekim kulturama, gdje su izraženije rodne razlike. https://www.pewforum.org/2016/03/22/women-and-men-about-equally-likely-to-believe-in-heaven-hell-and-angels/, Pristupljeno, 28.09.2020.
} 
u postojanje dženeta/raja, džehenema/pakla i meleka/anđela, osim manjih razlika koje su više kulturološki uvjetovane.

\subsection{Obredna dimenzija}

Jedan dio pitanja se odnosio na obredoslovlje, odnosno na to koliko muslimanke i muslimani prakticiraju svoju religiju kroz molitvu, odlazak u džamiju, obavljanje hadža (hodočašće u Meku, čitanje Kur'ana i druge obrede. Obredi su važan dio svake religije i, kako Emil Durkheim pojašnjava, oni sakraliziraju društveno, afirmiraju zajedništvo i omogućavaju da se ljudi lakše nose sa fragmentacijom života $(1954,121)$. Obred je, kako definira Ivan Cvitković $(2014,20)$ "simbolička radnja koja se vrši po prihvaćenim pravilima, kroz koja se izražavaju, religijske ideje, predodžbe, osjećaji i pomoću kojih se želi utjecati na Nadnaravno.” Đuro Šušnjić definiciju sažima na sljedeći način: "Obred je telesno organizovanje verskog iskustva... Telesni pokreti usmereni su, svesno i voljno, stilizovano i opetovano, na prisustvo apsolutne i mistične stvarnosti: to je svesno uključivanje tela u okviru načela vere.” $(1998,161)$. Međutim, obred ima još jednu funkciju, kako zaključuje Ivan Markešić (2010, 532), a to je osnaživanje osjećaja zajedništva i pripadnosti grupi.

Kao mikrokozmos društvenih i kulturnih vrijednosti, obredi omogućavaju članovima zajednice da prepoznaju i razumijevaju moć jedinstva, ali i da kreiraju posebnu vrstu raspoloženja i emocionalnog zanosa koji Durkheim naziva "collective efervescence" (kolektivnim zanosom) (1954, 474-475). Kada jednom osjete taj zanos i emocionalnu povezanost, vjernice i vjernice to žele ponovo doživjeti i zbog toga odlaze na zajedničke obrede. U svemu tome kako Pierre Bourdieu (1987) kaže, važna je uloga simbola koji se koriste u obredima, kao što je primjerice Kaba u Meki koja je centar molitve muslimana, ili ezan poziv na molitvu ili tespih (brojanica), ili određena vrsta odjeće kao što je ahmedija (kapa koju imam nosi tokom molitve), ili određena vrsta pokreta tokom molitve. Ovi i drugi simboli pomažu da se obred strukturira na određen način i da preko simbola, i kroz repetitivno izgovaranje svetog teksta, praćenog određenim pokretima prenesu na vjernice i vjernike osjećaj moći da su u stanju razumjeti nadnaravno preko društvenih formi komunikacije. Dakle, obredi su za vjernice i vjernike jedna vrsta kanala komunikacije sa transcendentnim.

Maurice Bloch (1992) će kasnije reći da i građanske, sekularne forme obreda imaju sličnu legitimirajuću moć i da kroz simbole osiguraju određenim grupama priznavanje prava da vladaju. Obredi u konačnici imaju važnu ulogu 
ne samo u povezivanju sa transcendentnim i sa cjelokupnim univerzumom, već i da praktikantima donesu psihološko olakšanje i rasterećenje od stresa, brige i teških životnih okolnostima. Kroz obrede vjernice i vjernici postižu jednu vrstu psihološke ravnoteže i sigurnosti.

U odnosu na vrlo visoku religijsku identifikaciju studentice i studenti su izjavili da u mnogo manjem procentu idu u džamiju obaviti molitvu (namaz): 16,7 procenata ide više od jednom sedmično, 19,9 ih ide u džamiju jednom sedmično, 5,6 procenata jednom mjesečno, 29,9 procenata samo za velike blagdane kao što su dva Bajrama, 17,9 procenata jednom godišnje, a 9,2 procenta uopće ne idu u džamiju. Zanimljivo je da muškarci u većem procentu posjećuju džamije od žena:

Tabela 5.

\begin{tabular}{lll}
\hline Koliko često posjećujete džamiju & Žene & Muškarci \\
\hline najmanje jednom sedmično & $13,1 \%$ & $28,5 \%$ \\
\hline više puta mjesečno & $15,0 \%$ & $22,2 \%$ \\
\hline
\end{tabular}

Veći broj muškaraca 28,5 procenata od ukupnog broja 16,7 procenata koji posjećuju džamije se može objasniti time što muškarci idu na džumu-namaz petkom, jer se to smatra njihovom obavezom. Većina nije navela razlog zašto ne odlazi u džamiju, a samo 3,6 procenata je dalo objašnjenje da je razlog to što se previše govori o politici. Čini se da mladi nisu željeli otkriti razloge zbog kojih povremeno ili vrlo malo odlaze u džamiju. Oni koji odlaze na molitvu u džamiju u najvećoj mjeri idu petkom na džuma-namaz (centralna molitva petkom), što se u islamskoj tradiciji posebno naglašava kao obavezujuće za muškarce, dok žene prema mainstream tumačenjima mogu obavljati ovu molitvu ako žele, ali nemaju obavezu. Zbog toga većina džamija u BiH i nema otvorene džamije za žene u vrijeme džuma-namaz molitve. U Sarajevu već decenijama postoji takva praksa u pojedinim džamijama, a novitet je što se sada u nekim drugim gradovima pozivaju žene da dolaze na ovu molitvu. Tako je Muftijstvo Zeničko donijelo odluku 2019. godine da se u sedam gradova ovog Muftijstva organizira džuman namaz za žene..$^{59}$

\footnotetext{
${ }^{59}$ Džuma-namaz je sedminčna obavezna molitva za svakog punoljetnog muslimana, prema mainstream tumačenju islama. Iako ženama nije zabranjeno odlaziti na ovu sedmičnu molitvu, kulturološki je prihvaćeno da samo muškarci odlaze u džamiju na ovu molitvu. Jedan od razloga koji se često navodi kao opravdanje zašto žene ne bi trebale dolaziti na ovu molitvu je i to što u džamijama nema dovoljno prostora ni zna sve muškarce i onda bi žene zauzele prostor džamije muškarcim kojima je to obaveza, a ženama nije stroga obaveza. Iako su žene u vrijeme prve zajednice muslimana i muslimanki u 7. Stoljeću odlazile na džuma-namaz zajedno sa muškarcima, vremenom je egalitarnu praksu zajedničke molitve potisnula praksa isključivanja žena iz džamija i to ne samo za džuma-namaz. Više o tome,
} 
$\mathrm{U}$ istraživanju nije postavljeno pitanje obavljanja molitve individualno $\mathrm{u}$ kući, jer to većina muslimana koji prakticiraju islam i čine, pa bi se na ovaj način moglo vidjeti da li u prakticiranju molitve u kući i džamiji ima značajnije razlike. Ako PEW istraživanje (2017) pokazuje da 69 procenata muslimana svoje duhovne potrebe ne ostvaruje u džamiji, već u privatnosti svoga doma, mogli bismo pretpostaviti da bi sličan procent muslimanki i muslimana to isto činio i u BiH.

S obzirom da se u islamskoj tradiciji čitanje, odnosno melodično recitiranje Kur'ana (učenje) ${ }^{60}$ na arapskom jeziku, ali prema nekim tumačenjima i čitanje prevoda arapskog originala karakterizira kao bogoštovlje (ibadet), očekivati je da to prakticiraju vjernice i vjernici. Iz odgovora saznajemo da je 88,8 procenata muslimanki i muslimana čitalo Kur'an, međutim, samo je 7,6 procenata onih koji to čine redovno, dok 9,6 procenata to čini nekoliko puta sedmično, 37,1 procenat ponekad, a 24,7 procenata vrlo rijetko. Dakle, vrlo mali procenat je onih koji redovno prakticiraju ovu vrstu bogoštovlja, odnosno čitanja teksta Kur'ana, ali 98,8 procenata ispitanika ima Kur'an u kući. Kada ove podatke razvrstamo po spolu onda vidimo da nema značajne razlike i da muškarci malo više nego žene čitaju Kur'an:

Tabela 6.

\begin{tabular}{lll}
\hline Koliko često čitate vašu svetu knjigu (Kur'an)? & Žene & Muškarci \\
\hline svaki dan & $3,1 \%$ & $3,8 \%$ \\
\hline više puta sedmično & $4,2 \%$ & $4,4 \%$ \\
\hline ponekad & 17,7 & $19,6 \%$ \\
\hline
\end{tabular}

Muslimanke i muslimani smatraju važnim da sveta knjiga bude na polici u kući, ponekad pažljivo umotana u ukrasnu kutiju ili platno i da se s ponosom ističe kako su Kur'an naslijedili od pradjeda ili pranane, što govori u prilog hereditarnoj formi religioznosti, koja se i u ranijim istraživanjima pokazala kulturološki imanentnom bosanskohercegovačkim muslimanima. (Spahić Šiljak, 2012). Posjedovanje određenih predmeta koji simboliziraju svetost $i$ uzvišenost, a posebno posjedovanje svetog teksta Kur'ana smatra se važnim,

\footnotetext{
vidjeti u Spahić Šiljak, Z. (2007). Žene, religije i politika. Pozitivni pomaci se događaju u zadnjih decenijama pa je i Savjet Muftijstva Zeničkog donio Odluku o organiziranju džuma-namaza za žene https:// www.islamskazajednica.ba/muftijstva-s/vijesti-iz-muftijstava/28312-savjet-muftijstva-zenickog-donio-odluku-o-organiziranju-dzuma-namaza-za-zene, 14.11.2019. Pristupljeno 22.10.2020.

${ }^{60}$ Muslimani koriste pojam učenje, umjesto pjevanje da bi napravili distinkciju između profanog i svetog i da bi melodično recitiranje Kur'ana po određenim pravilima razlikovali od običnog pjevanja.
} 
i odraz je pobožnosti, koja bi se mogla definirati kao narodna pobožnost a koja nije praćena konkretnim obredom.

\subsection{Intelektualna dimenzija}

Iako sociolozi religije religioznost mjere preko pet navedenih dimenzija religioznosti, ovo istraživanje nije uključilo pitanja na temelju kojih bi se mogla analizirati iskustvena i posljedična dimenzija religioznosti, pa ćemo iz postojećeg materijala analizirati intelektualnu dimenziju koja se odnosi na stupanj poznavanja normi i propisa islama.

Većina muslimanki i muslimana 95,2 procenta je izjavila da je pohađala vjeronauku, a od toga 90,8 procenata su vjeronauku pohađali u školi, a samo 4,8 procenata u islamskoj zajednici koja se inače organizira u lokalnim džamijama, i to uglavnom vikendom. Ovako veliki procent pohađanja vjeronauke, nije garant da su mladi u $\mathrm{BiH}$ uistinu religijski i obrazovani, niti da su u velikoj mjeri praktikanti religije, što se pokazalo u obrednoj dimenziji religioznosti. Međutim, odgovori na postavljena pitanja pokazuju da muslimanke i muslimani uglavnom znaju osnovne informacije o svojoj religijskog tradiciji.

Većina zna je muslimanski pozdrav selam i njih 89,2 procenta su tačno odgovorili, dok je 62,0 procenta znalo da su mjesec i zvijezda simboli islama. Međutim, vrlo mali broj 17,9 procenata je tačno odgovorio da je naziv za obavezni milodar u islamskoj tradiciji sadaka (arap. sadaqah), i većina nije znala odgovorit na pitanje da li obrezivanje spada u pet temeljnih načela islama.

Kao i svaka religijska tradicija i islam ima svoja temeljna načela i sljedećih pet muslimanke i muslimani imaju obavezu pridržavati ih se: 1 . šehadet (svjedočenje da je jedan Bog i da je Muhamed Božiji Poslanik), 2. namaz (pet dnevnih molitvi), 3. ramazanski post, 4. zekat (obavezni porez od 2,5 procenta), 5. hadž (hodočašće u Meku).

Velika većina muslimanki i muslimana je pokazala da poznaje osnovna načela islama.

Tabela 7.

\begin{tabular}{ll}
\hline Osnovan načela islama & Muslimani/ke \\
\hline šehadet & $83,3 \%$ \\
\hline namaz & $97,2 \%$ \\
\hline post & $98,4 \%$ \\
\hline zekat & $92,00 \%$ \\
\hline hadž & $93,2 \%$ \\
\hline
\end{tabular}


Ako 7,6 procenata ispitanika kaže da svaki dan čitaju Kur'an, a 9,6 procenta nekoliko puta sedmično, a 37,1 procenta da to čine samo ponekad, to znači da vrlo mali broj poznaje svoju svetu knjigu. Samo je 19,9 procenata muslimanki i muslimana odgovorilo da zna koja poglavlja čine Kur'an a od toga su 18 procenata studenti/ice Fakulteta islamskih nauka, što znači da je samo 1,9 procenata drugih studenata znalo ovaj odgovor. Kada je trebalo da navedu naziv za poglavlja, a ne imena svakog poglavlja, samo je 21,9 procenata odgovorilo da je to sura (arap. suretun-poglavlje), a od toga je 20,45 procenata procenta onih koji su studenti/ice Fakulteta islamskih nauka. To znači da je samo 0,64 procenta drugih studenata znalo odgovor.

Većina uopće nije znala odgovor, a 29,1 procent onih koji su dali netačne odgovore, jer su rekli da su to: ajeti, hadisi, džuzevi, kućanski harfovi i slično. Na pitanje koje se odnosilo na poznavanje pet dnevnih molitvi (namaz), odgovorilo je tačno 58,2 ispitanika i ispitanica.

Prilično veliki procent ispitanica $i$ ispitanika je pokazao da poznaje strukturu Islamske zajednice u $\mathrm{BiH}$, na čijem čelu se nalazi poglavar sa titulom reis ul-ulema. Ova titula se odnosi na velikog muftiju od 1881. godine kada Bošnjaci traže od austrougarskih vlasti da im dozvole da imenuju reis-ul ulemu. Kada je to dozvoljeno, formirano je tijelo pod nazivom Ulema-imedžlis (Savjet učenjaka) i tim je činom Islamska zajednica u BiH i zvanično bila odvojena od Istanbula (Islamska Zajednica). ${ }^{61}$ Danas se u svakodnevnom javnom diskursu koristi samo reis kao skraćeni naziv ove titule, ali kada se radi o zvaničnim saopćenjima onda se ipak navodi puni naziv reis-ul-ulema. S obzirom da je danas mnogo više nego ranije Islamska zajednica prisutna u medijima, sa svojim socijalnim mrežama, časopisima, radiom i televizijom, te da reis ul-ulema često istupa u javnosti, onda je očekivano da muslimani znaju da je reis ul-ulema na prvom mjestu u hijerarhiji ove institucije. Studentice i studenti su također pokazali da znaju da je muftija druga a imam treća osoba po važnosti u strukturi Islamske zajednice, pa je 76,1 procenat njih odgovorio tačno za poziciju muftije, a 73,7 procenata su tačno odgovorili za poziciju imama.

U odnosu na prilično dobro poznavanje ključnih pozicija u strukturi Islamske zajednice poznavanje povijesti islama je na niskoj razini. Samo je 10,8 procenata znalo da se muslimanski kalendar računa od 622 . godine po Gregorijanskom kalendaru, kada je poslanik Muhammed nakon 13 godina svoje poslaničke misije tokom koje je iskusio pritiske i izolaciju, preselio iz

\footnotetext{
${ }^{61}$ Više o instituciji Rijaseta i reis ul-uleme u Islamskoj zajednci Bosne i Hercegovine vidjeti na: https:// www.islamskazajednica.ba/institucija-reisu-l-uleme , Pristupljeno, 02.10.2020.
} 
Meke u Medinu i tamo osnovao prvu zajednicu muslimana. S obzirom da muslimanke i muslimani u BiH obilježavaju Hidžretsku novu godinu i da je to u zadnjim decenijama popularizirano u medijima, iznenađuje da vrlo mali broj ispitanika zna od kada se računa Hidžretski kalendar. Većina (99,2 procenta) je pogrešno odgovorila da je muslimanska nova godina jedan od dva najpoznatija blagdana kod muslimana. Također je iznenađujuće da većina nije znala odgovor na pitanje da li je rođendan poslanika Muhameda jedan od dva najpoznatija islamska blagdana.

U analizi podataka koji se odnose na vlastiti religijski identitet i poznavanje islama i islamskih načela, vidljivo je da se veliki broj studentica i studenata deklariraju kao muslimani i muslimanki ali da nesrazmjerno manji broj njih prakticira molitvu u džamiji. Također, većina dobro poznaje osnovna načela islama i strukturu Islamske zajednice, ali je njihovo znanje vrlo nisko kada je u pitanju povijest islama i sadržaj teksta Kur'ana.

\section{Koliko poznajem druge toliko ih poštujem?}

Da li su današnji sukobi i ratovi rezultat nepoznavanja drugih kultura i religija? Da li je za izgradnju kulture mira dovoljno poznavati druge kulture i tradicije i šta podrazumijevamo pod poznavanjem? Koliko je religijski ekskluzivizam prekriven formalnim opredjeljenjem za dijalog? Da li i u kojoj mjeri su prisutni pozitivni autostereotipi i negativni heterostereotipi? Sve su ovo važna pitanja koja postavljamo i u analizi istraživanja "Koliko se poznajemo?"

Ako je religija moćan izvor legitimiteta za političke strukture moći, što je posebno izražajno u onim religijama koje su povijesno povezane sa etničkom zajednicom (Vukomanić, 2008, 178) kao što je slučaj na Balkanu, religija također može biti resurs za izgradnju mira i pomirenja. Ambivalentnost svetog (Appleby, 2000), koje s jedne strane može biti korišteno da opravdava isključivanje i nasilje, a s druge strane služiti kao poticaj za nenasilje i izgradnju mira, otvara mogućnost za cjelovitiji pristup ulozi religije u izgradnji kulture mira. Ako se doista želi graditi kultura mira, onda je potrebno upoznati drugoga u cjelini, a ne samo jednu stranu i to onu koja koja se ideološki zloupotrebljava za promociju nasilja. Ovo istraživanje pokazuje koliko zapravo muslimanke i muslimani poznaju svoje komšije i koliko to utječe na njihove stavove o drugima. 


\subsection{Koliko muslimani poznaju jevreje, katolike, pravoslavce i nereligiozne?}

Kako je već na početku ovog poglavlja kazano u BiH se uglavnom preklapaju etnički i religijski identiteti pa se Hrvati deklariraju kao katolici, Srbi kao pravoslavni, a Bošnjaci kao muslimani. Da li muslimani kao najbrojniji (50,7 procenata ukupne populacije) pokazuju više ili manje socijalne distance u odnosu na svoje komšije jevreje, katolike i pravoslavne, odnosno da li više poznaju svoje komšije nego što oni poznaju njih? Rezultati ovog istraživanja daju odgovore koliko studenti muslimanke i muslimani znaju o judaizmu i kršćanstvu i da li imaju stereotipe jedni prema drugima.

\subsubsection{Biblija}

Monoteističke religije judaizam, kršćanstvo i islam se smatraju religijama knjige, jer se njihovo vjerovanje temelji na objavi od Boga koja je sabrana u Bibliji i Kur'anu. Biblija je sveta knjiga kršćana i uz ličnost Isusa Krista/Hrista koji je temelj kršćanske vjere, važan je izvor vjerovanja, normi i propisa. Kršćani vjeruju da je Isus Sin Božiji i Mesija (hebr. mashiah, grčki: Kristos) da je došao nagovijestiti kraljevstvo Božije. Biblija (grč. biblia - knjižice) je za kršćane Božija riječ kojom su bili nadahnuti njeni pisci kroz period više od hiljadu godina. Sastoji se od dva dijela: Stari zavjet (hebrejski i aramejski spisi judaizma, koje jevreji zovu Hebrejska Biblija ili Torah, iako se Torah odnosi na prvih pet knjiga Mojsijevih) i Novi zavjet: 4 evanđelja, 13 poslanica sv. Pavla, 8 drugih poslanica i Ivanovo otkrivenje (France, 1987, 369).

Biblija nije samo sveta knjiga kršćana, već se smatra književnim i umjetničkim djelom opće kulture na Zapadu, stoga je bilo zanimljivo vidjeti da li muslimanke i muslimani čitaju Bibliju, da li je imaju u svojoj kućnoj biblioteci i da li znaju njen sadržaj. Na pitanja da li u kući imaju Bibliju, samo je 8,8 procenata muslimanki i muslimana odgovorilo potvrdno (od tog broja 18,18 procenata studenata/ica Fakulteta islamskih nauka), dok je 17,9 \% studenata katolika, a 27,3 procenta pravoslavnih izjavilo da u kući posjeduju Kur'an. Iako mali broj muslimana posjeduje Bibliju u svojoj kućnoj biblioteci, 15,1 procenata ih je čitalo Bibliju, dok je 25,0 procenata katolika, a 27,3 procenta pravoslavnih čitalo Kur'an.

Sljedeće pitanje se odnosilo da poznavanje strukture Biblije: 33,9 procenata studenata muslimanki i muslimana je tačno odgovorilo da je prvi dio Biblije Stari Zavjet, a 34,7 procenata je navelo da je Novi Zavjet drugi dio Biblije. U sličnom omjeru 33,67 procenata su odgovorili i katolici da se 
Kur'an sastoji od sura (poglavlja), a samo je 11,2 procenta pravoslavnih je tačno odgovorilo na ovo pitanje. Na pitanje ko su pisci četiri Evanđelja, 24,7 procenata muslimanki i muslimana su odgovorili tačno, a 19,2 procent su djelomično tačno odgovorili.

Tabela 8 .

\begin{tabular}{ll}
\hline Pisci Evanđelja & Muslimanke i Muslimani \\
\hline Marko, Luka, Ivan i Matej & $24,7 \%$ \\
\hline Matej, Luka, Ivan i Petar & $8,8 \%$ \\
\hline Matej, Luka, Ivan, Pavle i Petar & $5,2 \%$ \\
\hline Ivan, Luka i Petar & $5,2 \%$ \\
\hline Ne znam & $49,0 \%$ \\
\hline
\end{tabular}

\subsubsection{Osnove vjerovanja i sveta mjesta}

\section{Osnove vjerovanja}

Svaka religija ima svoje principe i načela koji su obavezujući za njene sljedbenike. U monoteističkim religijama koje se često nazivaju i abrahamske religije, Bog je jedan, ali se različito predstavlja i štuje. Iako se u sve tri religijske tradicije Abraham/Ibrahim smatra praocem monoteizma samo je 41,8 procenata muslimanki i muslimana odgovorilo da su judaizam, kršćanstvo i islam abrahamske religije. Ostali ispitanici su navodili ili samo islam i kršćanstvo ili judaizam i kršćanstvo, ili čak kombinaciju kršćanstva judaizma i budizma.

U judaizmu se Božije ime Jahve ne izgovara iz poštovanja prema Bogu, kako se naglašava u Bibliji: "Ne izgovaraj uzalud ime Jahve, Boga svoga" (Izl. 20,7), pa se umjesto toga koristi riječ Adonai - Gospodin. U islamu je ime za Boga Allah i najćešće se ova arapska riječ ne prevodi, već se koristi kao vlastito ime, dok se u kršćanstvu ime Boga veže za Isusovu ličnost.

U kršćanstvu i u pravoslavnoj i katoličkoj tradiciji vjeruje se u jednog Boga koji je trinitarno određen sa tri nerazdjeljiva lica: Otac nebeski, Sin Isus Krist i Sveti Duh. Isus Krist/Hristos je došao je na zemlju u liku čovječijem radi spasenja ljudi. Rodila ga je Bogorodica (grč. teotokos) -Marija bezgrešnim začećem, zbog čega se ona posebno štuje i u katoličkoj crkvi u Hrvatskoj se razvio čitav kult štovanja Marije - mariologija.

Jedno od važnih pitanje u ovom istraživanju bilo je da li muslimani i kršćani vjeruju u istog Boga? Odgovori ispitanika sve tri konfesije su vrlo slični, i većina smatra da svako vjeruje u svoga Boga. Interesantno je to što 
i muslimani često ističu kur'ansku poruku o tome da muslimani, kršćani i jevreji vjeruju jednog Boga, ali da je manje od trećine ispitanika u ovom istraživanju odgovorilo da vjeruju u to.

Tabela 9.

\begin{tabular}{lll}
\hline Vjera u istog Boga? & Potpuno se slažem & Djelomično se slažem \\
\hline muslimani & $23,1 \%$ & $25,5 \%$ \\
\hline pravoslavni & $26,3 \%$ & $26,3 \%$ \\
\hline katolici & $25,0 \%$ & $21,4 \%$ \\
\hline
\end{tabular}

U svojoj knjizi Allah-kršćanski odgovor, Miroslav Wolf (2015, 143) iznosi argumente o tome da se u normativnom kršćanstvu i normativnom islamu Božija narav opisuje na isti način: 1. Bog je jedan, 2. Bog je stvoritelj, 3. Bog se razlikuje od svijeta, 4. Bog je dobar, 5. Bog zapovjeda ljubav prema Bogu, 6. Bog zapovijeda ljubav prema bližnjem. Iz ovoga proizlazi da kršćani i muslimani misle na istog Boga, ali štuju različite Bogove. Unatoč zajedničkim normativnim polazištima, trinitarni karakter Božije osobe ostaje pitanje prijepora. Ovo je vjerovatno razlog zbog kojeg su i kršćani i muslimani $\mathrm{u}$ malom broju potvrdili da vjeruju u istog Boga. Iako muslimani u međureligijskim susretima naglašavaju kur'ansku poruku u kojoj Bog kaže: "A vaš Bog jedan je.” (Kur'an 2, 163), ne prihvaćaju da se jedan Bog predstavlja u tri osobe, a to je posebno izraženo u razumijevanju uloge Isusa Krista/Isa Poslanika koji je za muslimane Božija Riječ (Kelimet Allah, Kur'an 3, 45-51) udahnut Merjemi (Marija) ali i dalje se ne smatra božanskom osobom.

Jedno od pitanja odnosilo se na deset Božijih zapovjedi (dekalog, Izl. 20, 3-14) koje su prema učenju sve tri monoteističke religija objavljene Mojsiju (Musa) na Sinaju kada je i sklopljen Savez između Boga i izabranog jevrejskog naroda koji je oslobođen iz egipatskog ropstva. Simbolično kroz deset prstiju na rukama jevreji dijele deset zapovjedi: pet prstiju desne ruke (milosrđe) predstavlja pet naredbi - odnos čovjeka prema Bogu, a pet prstiju lijeve ruke (strogoća) odnos prema drugim ljudima (Kristić, 2009, 54-55).

Polovica muslimanki i muslimana 50, 2 procenta su odgovorili da je Bog deset zapovjedi objavio Mojsiju, međutim vrlo mali procent je naveo šest zapovijedi 0,4 procenta, a dvije ili tri zapovjedi je navelo 1,8 procenata, dok niko nije znao navesti svih deset. Ako se još ima u vidu da 13,4 procenta ispitanika dolazi sa Fakulteta islamskih nauka, onda je to iznenađujuće. Deset Božijih zapovijedi, kako ističe Enes Karić, također sadržane i u Kuranu, iako 
nisu nabrojane na jednom mjestu (2005, 307-316). Tim više je onda iznenađujuće da muslimanke i muslimani ne znaju više o deset zapovijedi.

Pravoslavke i pravoslavci, kao i katolkinje i katolici vjeruju u sedam svetih sakramenata, odnosno sedam svetih tajni koje se u katoličkoj i pravoslavnoj tradiciji razlikuju samo u nazivu i poretku: 1. krštenje, 2. krizma/miropomazanje (potvrda), 3. sveta misa/pričest, 4. ispovijed/pokajanje, 5. bolesničko pomazanje/jeleosvećenje, 6. svećenički red, 7. ženidba. Zanimljivo je da su muslimanke i muslimani u vrlo malom procentu znali koji od obreda spadaju u svete sakramente

Tabela 10.

\begin{tabular}{lll}
\hline Sveti sakramenti & Muškarci & Žene \\
\hline Da li je krštenje sveti sakrament? & $5,1 \%$ & $1,9 \%$ \\
\hline Da li je krizma sakrament? & $13,8 \%$ & $11,4 \%$ \\
\hline Da li je ispovijed/pokajanje sakrament? & $5,1 \%$ & $6,5 \%$ \\
\hline Da li je svećenstvo sakrament? & $17,7 \%$ & $21,5 \%$ \\
\hline Da li je bolesničko pomazanje/ sakrament? & $22,7 \%$ & $26,2 \%$ \\
\hline Da li je ženidba/brak sveti sakrament? & $12,7 \%$ & $11,5 \%$ \\
\hline Da li je sveta misa/pričest sveti sakrament? & $6,7 \%$ & $3,8 \%$ \\
\hline
\end{tabular}

Primjerice, krštenje, krizma i ispovijed su tri sakramenta za koje bi većina trebala znati, jer ako poznaju svoje komšije kao što često tvrde, onda bi trebali znati da se djeca krste i da u ranom punoljetstvu primaju sakrament krizme, potvrde svoje vjere i da se katolici ispovijedaju za svoje grijehe. Na koncu, krizma/miropomazanje je svečani trenutak i u katoličkoj i pravoslavnoj porodici i djeca se posebno spremaju za to, pa je iznenađujuće da ako muslimani kažu da poznaju svoje komšije katolike i pravoslavce da ih ukupno 25,2 procenta znaju da je krizma/miropomazanje jedan od sakramenata.

Također, treba vidjeti da li to znači da mladi na pravoslavnoj i katoličkoj vjeronauci imaju više sadržaja o islamu, nego što mladi na islamskoj vjeronauci uče o pravoslavlju i katoličanstvu. Iako je u kontrolnoj grupi bilo po deset studenata islamske teologije, to dodatno iznenađuje da muslimanke i muslimani vrlo malo znaju o svetim sakramentima. Ako to usporedimo sa odgovorima koje su dali katolici i pravoslavni u vezi sa pet osnovnih načela islama, onda je nesrazmjer ogroman, kako se vidi vidu u narednoj tabeli: 
Tabela 11 .

\begin{tabular}{lll}
\hline Osnovna načela islama su & Pravoslavni & Katolici \\
\hline šehadet & $98,6 \%$ & $53,6 \%$ \\
\hline namaz & $98,9 \%$ & $73,2 \%$ \\
\hline post & $98.7 \%$ & $67,9 \%$ \\
\hline zekat & $98,4 \%$ & $44,6 \%$ \\
\hline hadž & $98,4 \%$ & $62,5 \%$ \\
\hline
\end{tabular}

Jedno od pitanja se odnosilo na najrasprostranjeniju kršćansku molitvu, pa je 68,5 procenata muslimanki i muslimana odgovorilo da je to molitva Oče naš, 7,6 procenata je odgovorilo da je to molitva Zdravo Marija, a ostali nisu znali. Prilično veliki broj ispitanika je znao odgovor na pitanju gdje kršćani idu nedjeljom: 87,4 procenata je odgovorilo da idu u crkvu na misu, odnosno na molitvu; 72,9 procenata muslimanki i muslimana je tačno odgovorilo da je katolički pozdrav Hvaljen Isus i Marija, a 63,7 procenata je tačno odgovorilo da je Pomoz Bog pozdrav pravoslavaca.

U manjem procentu muslimanke i muslimani su znali da je sinagoga jevrejski hram, pa je samo njih 39,1 pocenat tačno odgovorilo. Bilo je i drugih odgovora: 2,0 procenta da je to Salomonov hram, 0,4 procenta da je Davidov hram, 2,0 procenta da je to Zid/hram plača, a ostali nisu znali odgovor. Mnogo veći procent $(55,0)$ muslimanki i muslimana su tačno naveli da je šalom jevrejski pozdrav.

\section{Obrezivanje}

Kada je u pitanju obred obrezivanja muške djece, to je vrlo važan obred inicijacije $u$ islamskoj i jevrejskoj tradiciji. U jevrejskoj tradiciji obrezivanje se obavlja osmog dana po rođenju dječaka, i u islamskoj tradiciji su slični propisi, s tim da se u pojedinim kulturama ovaj obred obavlja u ranom djetinjstvu i predstavlja veliki događaj i slavlje za porodicu.

Muslimani su preuzeli obrezivanje iz jevrejske tradicije kao jednu od obrednih praksi koja je postojala i prije islama u drugim kulturama. $\mathrm{Na}$ pitanje u kojoj religijskoj tradiciji se prakticira obrezivanje: 92,0 procenta muslimanki i muslimana je odgovorilo da je obrezivanje (sunećenje) obredna praksa u islamskoj tradiciji, 34,7 procenata je odgovorilo da se obred obrezivanja prakticira i u jevrejskoj tradiciji, 8,4 procenta su rekli da katolici prakticiraju obrezivanje, a 4,0 procenta da je ovaj obred prisutan i kod pravosla- 
vaca. Iako je obrezivanje važan obredna praksa kod jevreja, značajno manji broj ispitanika je to prepoznao. ${ }^{62}$

\section{Sveta mjesta}

U nastavku analiziramo odgovore muslimanki i muslimana o tome koliko poznaju sveta mjesta judaizma, pravoslavlja i katoličanstva. Na pitanje koji gradovi su važni za kršćane, jevreje i muslimane, 61,8 procenata je odgovorilo da je to Jerusalem, 14,7 procenata da je to Meka, 4,4 procenta da je to Istanbul i 1,2 procenta da je to Rim. Zanimljivi su odgovori na ovo pitanje, jer je većina odgovorila da je to Jerusalem koji je iznimno važan za sve tri religijske tradicije - ostaci Jevrejskog hrama (Zid plača) koji je izgradio Solomon (Sulejman) nalaze se u Jerusalemu koji je bio centar jevrejskog religijskog života, a i danas je; Kupola na stijeni sa džamijom je također u Jerusalemu koji je za muslimane bio prva kibla (smjer u kojem su se okretali u molitvi, pa je kasnije prihvaćeno da to bude Meka) i danas je jedan od tri sveta grada, pored Meke i Medine. Jerusalem je ključan i za sve kršćane zbog Isusa Krista koji svoj križni put prošao u ovom gradu i čiji grob, iz kojeg se vjeruje da je uskrsnuo, nalazi u crkvi u Jerusalemu (Cvitković, 2002; Spahić Šiljak i Abazović, 2009).

\subsubsection{Struktura crkava i Jevrejske zajednice}

Katolička i pravoslavna crkva su hijerarhijski ustrojene zajednice i premda je struktura slična postoje razlike kako u nazivima crkvenih duhovnih vođa, tako i u načinu funkcioniranja crkve.

Muslimanke i muslimani su pokazali da ne znaju dovoljno o povijesnom razvoju kršćanstva i ključnim prekretnicama kao što je šizma koja se dogodila u 11. stoljeću - podjela kršćanstva na Istočno (pravoslavnog obreda) i Zapadno (rimokatoličkog obreda). Samo je 38,2 procenta njih odgovorilo da se raskol dogodio 1054. godine.

Raskoli su prisutni i svim religijskim tradicijama, na šta su utjecala razilaženja u teološkim tumačenjima principa vjere, a ponajviše politička previranja za prevlast i moć. Od vremena raskola pa do danas pravoslavne i katoličke crkve su prošle različit razvojni put i one imaju svoje specifičnosti na

\footnotetext{
${ }^{62}$ Zanimljivo je da se zadnjim decenijama na ovim prostorima pojavila praksa obrezivanja ženske djece, koja se u zvaničnim tumačenjima islama u $\mathrm{BiH}$ ne odobrava. Ovaj plemenski običaj preuzele su pojedine muslimanske zemlje u Africi i Aziji, a danas preko 40 zemalja prakticira obrezivanje žena. U međunarodnim dokumentima ljudskih prava ovaj obred se tretira kao genitalna mutilacija i predstavlja ogroman rizik po zdravlje i služi kao mehanizam kontrole ženske seksualnosti. (Abdulcadir et.al. 2017).
} 
Balkanu i u BiH jer su i nacionalne crkve, kao što je Srpska pravoslavna crkva (Cvitković, 2002).

Kako je BiH bila i granica i mjesto susreta Bizanta i Rima, Istoka i Zapada, tako su se na ovom prostoru međusobno susretale i prožimale Katolička i Srpska pravoslavna crkva. U BiH Katolička crkva djeluje kroz instituciju Nadbiskupije Vrhbosna sa sjedištem u Sarajevu, a pripadaju joj i Banjolučka, Mostarsko-duvanjska i Trebinjsko-mrkanska biskupija. Vrhovni duhovni autoritet svih katolika je papa (aktuelni je Papa Franjo) koji stoluje u Rimu, a vrhovni autoritet u BiH je kardinal (aktuelni Vinko Puljić).

Pravoslavna crkva u $\mathrm{BiH}$ postoji stoljećima, ali u različitim historijskim periodima bila pod autoritetom različitih duhovnih centara. Na Balkanu postoje autokefalne crkvene zajednice koje se poistovjećuju s narodom (Šećibović, 1995, 89). Od 1920. godine Pravoslavna crkva iz BiH postala je dio Srpskepravoslavne crkve sa sjedištem u Beogradu koja pripada Carigradskom ekumenskoj parijaršiji. Postoje još i Aleksandrijska, Antiohijska i Jerusalemska patrijaršija. Vrhovni autoritet je patrijarh (aktuelni Irinej). U BiH djeluje pet eparhija: Eparhija Banjolučka, Eparhija Bihačko-petrovačka, Eparhija Zahumskohercegovačka, Eparhija Zvornička i Eparhija Dabrobosanska čije je sjedište Sarajevo, a sada je izmješteno na Sokolac (Hrvatska enciklopedija).

Jevrejska zajednica BiH je vrlo važna tradicionalna religijska zajednica iako danas ima vrlo malo članova, jer je općenito vrlo malo jevreja ostalo u BiH i najveći broj živi u Sarajevu, gdje je i sjedište Jevrejske opštine. Najveći egzodus se dogodio u Drugom svjetskom ratu i u posljednjem radu (19921995), veliki broj je emigrirao u Zapadne zemlje i Izrael. Jevreji su došli u BiH u 16. stoljeću nakon progona iz Španije i oni se nazivaju Sefardi i imaju svoj specifični jezik Ladino (kombinacija hebrejskog i španskog), a oni koji su se doselili iz Njemačkog govornog područja su Aškenazi i govore Aškenaski jezik (kombinacija hebrejskog i njemačkog). Jevrejska zajednica nema stalnog rabina koji je duhovni učitelj i vođa zajednica već ima predsjednika (aktuelni Jakob Finci), a rabin dolazi samo za vrijeme velikih blagdana. ${ }^{63}$

Podaci u sljedećoj tabeli pokazuju da muslimanke i muslimani u velikom procentu znaju ko su religijske vođe religijskih zajednica. Najveći procent prepoznaje papu kao religijskog vođu i najveći duhovni autoritet katolika. Razlog tome može biti što je papa Franjo često prisutan i medijima i što su on i prethodni papa Ivana Pavao drugi posjetili Sarajevo. To su bili važni

\footnotetext{
${ }^{63}$ Više tome vidjeti na web stranici Jevrejske opštine Sarajevo: https://www.jews.ba/Menu/4/JC-Sarajevo, Pristupljeno, 4. 10. 2010.
} 
historijski, politički, kulturni i religijski događaji u BiH i s obzirom da su i medijski bilo dobro praćeni veliki broj ljudi je vjerovatno zapamtio. U mnogo manjem procentu muslimanke i muslimani znaju o vrhovnim autoritetima $\mathrm{u}$ pravoslavlju, s tim da muškarci u većem procentu nego žene znaju odgovor na ovo pitanje.

Tabela: 12 .

\begin{tabular}{lll}
\hline Religijske vođe & Muškarci & Žene \\
\hline papa je religijski vođa katolika & $62,0 \%$ & $51,5 \%$ \\
\hline biskup je religijski vođa katoličke zajednice & $54,4 \%$ & $48,5 \%$ \\
\hline patrijarh je vođa pravoslavne zajednice & $50,6 \%$ & $42,5 \%$ \\
\hline mitropolit je vođa pravoslavne zajednice & $44,9 \%$ & $34,2 \%$ \\
\hline gvardijan upravlja samostanom & $29,0 \%$ & $16,5 \%$ \\
\hline iguman upravlja manastirom & $34,2 \%$ & $31,9 \%$ \\
\hline rabin je religijski vođa jevrejske zajednice & $50 \%$ & $43,5 \%$ \\
\hline
\end{tabular}

\section{Redovničke zajednice}

$\mathrm{U} \mathrm{BiH}$ su prisutne različite katoličke redovničke zajednice, a svakako su najpoznatije Dominikanci, Isusovci i Franjevci (Cvitković, 2002, 191-194). Na pitanje koje su najpoznatije katoličke redovničke zajednice vrlo mali broj muslimanki i muslimana je znao odgovor. Samo je 9,2 procenata ispitanika odgovorilo da su to Franjevci, iako su Franjevci i Bosna Srebrena veoma poznati i cijenjeni u $\mathrm{BiH}$ i iznenađuje da muslimanke i muslimani vrlo malo znaju o tome. Na koncu, u Visokom postoji Franjevačka gimnazija, koju su pohađali i danas pohađaju i muslimani, zatim u Fojnici, Kraljevoj Sutjesci, Sarajevu i drugim gradovima postoje franjevački samostani koji su i vrijedno kulturno-historijsko blago BiH. Stoga je iznenađujuće da je tako mali broj ispitanika spomenuo Franjevce. Između ostalih zajednica ispitanici su naveli još i Dominikance, ali samo je 0,8 procenata navelo ovaj podatak.

Iako je vrlo niska razina znanja o strukturi katoličke i pravoslavne crkve, većina muslimanki i muslimana je odgovorila da su posjetili hram druge vjerske zajednice: 21,9 procenata kao gost, 24,7 procenata iz radoznalosti, 21,1 procent kao turisti. Ostali su odgovorili da nisu imali priliku a 4,0 procenata je odgovorilo da ne bi ušli u hram druge vjerske zajednice. Sljedeće pitanje se odnosilo na to da li su pripadnici druge vjerske zajednice posjetili džamiju? Rezultati pokazuju da 18,3 procenta muslimanki i muslimana da znaju da su pripadnici drugih religija posjetili džamiju, a 47,0 procenata je 
odgovorilo da znaju kako su pripadnici drugih religija posjetili džamiju kao turisti. Procent onih koji su izjavili da su posjetili hram druge religijske zajednice je približan procentu onih koji znaju da su pripadnici drugih religijskih zajednica posjetili njihov hram, odnosno džamiju.

\section{Druge zajednice}

Na pitanje koje još zajednice pored muslimana, katolika, pravoslavnih i jevreja postoje u $\mathrm{BiH}$, muslimanke i muslimani su naveli više religijskih tradicija, uključujući i budizam i hinduizam, ali je zanimljivo da su protestante i jehovine svjedoke navodili kao posebne religijske tradicije, a ne kao kršćanke denominacije.

Tabela 13.

\begin{tabular}{ll}
\hline Druge religijske zajednice u BiH & Da \\
\hline protestanti & $2,0 \%$ \\
\hline budisti & $2,4 \%$ \\
\hline jehovini svjedoci & $2,8 \%$ \\
\hline hinduizam i hare krišna & $1,2 \%$ \\
\hline romske & $1,2 \%$ \\
\hline šamanizam & $0,4 \%$ \\
\hline ateisti i pripadnici sekti & $1,4 \%$ \\
\hline
\end{tabular}

Iako muslimanke i muslimani pokazuju određenu razinu poznavanja osnova vjere, obreda, simbola i strukture jevreja, katolika i pravoslavaca, navedeni podaci pokazuju da je znanje o drugim religijskim zajednicama koje su manjina u BiH izrazito na niskoj razini, jer manje od 3 procenta ispitanika jedva znaju da postoje manjinske religijske zajednice u ovoj zemlji.

\subsubsection{Simboli i blagdani jevreja, katolika i pravoslavaca}

\section{Simboli}

Svaka religija ima svoje simbole po kojima je prepoznatljiva. Simbol kršćanstva je križ/krst. Križ prisutan i na drugim mjestima, osim crkve, a vjernice i vjernici ga često nose kao lančić. Kako navodi Ivan Cvitković: "Nijedan kršćanski obred se praktično ne obavlja bez križa koji simbolizira mučeničku smrt.” (2002, 184). Znak koji se nalazi na križu sadrži akronim INRI (Jesus Nazarenus Rex Israel - Isus iz Nazareta, kralj Izraelski). Križ/krst nije samo 
simbol mučeništva Isusa Krista, već i simbol nade u uskrsnuće i novi život. Sa dva pola označava duhovnu vertikalu i zemaljski život (Steffler, 2002, 27).

Simbol Judaizma je Davidova zvijezda (hebr. magen David: Davidov štit). Dva jednakostrana trokuta spojena u heksagram označavaju prožimanje vidljivog i nevidljivog svijeta. U 18. stoljeću će na Prvom cionističkom kongresu u Baselu Davidova zvijezda postati jevrejski nacionalni amblem, a kasnije će biti na zastavi države Izraela (Da-Don 2004, 326-327).

Veliki broj muslimanki i muslimana 79,5 procenata je odgovorio kako je simbol kršćanstva križ/krst, dok je samo 26,7 procenata tačno odgovorilo da je jevrejski simbol Davidova/Davudova zvijezda, ili samo zvijezda. Njih 2,8 procenata su rekli da je to petokraka zvijezda, 2,4 procenta da je to šestokraka zvijezda, a ostali nisu odgovorili ili su rekli da ne znaju. S obzirom da je malo jevreja u $\mathrm{BiH}$ i da je simbol križ/krst mnogo više prisutan kako u crkvama, tako i u drugim institucijama, ali i u medijima i popularnoj kulturi, onda ne iznenađuje da su ga ispitanici u većem procentu prepoznali kao simbol kršćanstva.

\section{Blagdani}

Bitan segment vjere i života jedne religijske zajednice je obilježavanje važnih blagdana. Muslimani imaju dva velika blagdana, a to su dva bajrama. Ramazanski-bajram se obilježava nakon mjesec dana posta i traje tri dana. Kurban-bajram se obilježava na kraju obreda hadža kada se prinosi žrtva (kurban) i traje četiri dana.

Jevreji imaju veliki broj blagdana, a najznačajniji su Jom Kipur i Pesah. Pesah je najpoznatiji i slavi se u znak sjećanja na oslobođenja Jevreja iz egipatskog ropstva. U noći sedera u porodičnom domu pripovijeda se o tom događaju, jede se beskvasni kruh matzot, a običaj je pozvati komšije, prijatelje i siromašne (Da-Don, 2004, 177). Jevreji u Bosni i Hercegovini Pesah obilježavaju u zajednici, a običaj je da pozovu komšije i prijatelje koji nisu Jevreji da s njima podijele radost ovog praznika.

Kršćani, katolici i pravoslavci svetkuju Božić i Uskrs, ali u različito vrijeme, zbog različitih kalendara koje slijede: pravoslavci slijede Julijanski kalendar koji je osmislio egipatski astronom Sizogen, a uveo ga je u upotrebu Gaj Julije Cezar; Gregorijanski kalendar je u 16. stoljeću uveo papa Grgur XIII i prihvatile su ga sve katoličke zemlje, a od 18. stoljeća i protestantske (Hrvatska enciklopedija). Stoga se Božić za katolike, protestante i pravoslavce zapadnog obreda obilježava 25. decembra, dok pravoslavci Božić 
obilježavaju 7. januara. Najveći kršćanski blagdan je Uskrs/Vaskrs, čiji se datum mijenja svake godine u mjesecima marta i aprila, a četrdesetodnevna priprema za Uskrs/Vaskrs je Korizma - vrijeme koje je Isus proveo u pustinji prije svoje misije (France, 1987, 370, Cvitković 2002, 175-231).

Pored ova dva velika praznika, katolici obilježavaju i Veliki petak, Duhove, Veliku Gospu i druge blagdane, dok pravoslavni obilježavaju Pravoslavnu novu godinu 14. januara, zatim krsnu slavu koja je specifična za svaku porodicu, ovisno o tome kojeg sveca svetkuju, Vidovdan, i druge blagdane (France, 1987, 370, Spahić Šiljak i Abazović, 2009).

Muslimanke i muslimani su pokazali da djelomično poznaju religijske blagdane svojih komšija, pa je 65,8 procenata odgovorilo da zna da se Pesah obilježava u čast izlaska jevreja iz egipatskog ropstva. Za vrijeme ovog blagdana jevreji čitaju Hagadu, međutim, samo manji broj muslimanki i muslimana, 24,4 procenta je znao odgovor na ovo pitanje. Iako je Hagada jedan od najpoznatijih muzejskih artifakata u $\mathrm{BiH}$ i popularizirana je i kroz književnost i kulturu, ipak najveći broj ispitanih nije znao da se upravo ova knjiga čita tokom Pesaha.

U većem broju, 80,1 procenat ispitanih je odgovorio da je Božić, odnosno rođendan Isusa Krista najznačajniji blagdan kršćana, dok je 12,0 procenata odgovorilo da je to Uskrs/Vaskrs, a 0,8 procenata je odgovorilo da je to Božić ili Uskrs, jer nisu bili sigurni koji je najznačajniji.

Razlog zašto je najveći broj prepoznao Božić a ne Uskrs kao najznačajniji blagdan može biti, kako objašnjava Stephen Nissenbaum, u tome što je Božić krajem 19. stoljeća ponovno izumljen kao buržoaski "civilizirani” i "tradicionalni" porodični blagdan $(1997,52)$.

Pored toga, u drugoj polovici 20. stoljeća je populariziran u filmskoj i zabavnoj industriji kao blagdan koji je u velikoj mjeri sekulariziran i komercijaliziran, ali i medijski eksploatiran, pa je tako postao integralni dio kulture Zapadnih ali velikoj broja Istočnih društava. Stoga je očekivano da se Božić doživljava kao najvažniji blagdan.

Kada je u pitanju krsna slava, odgovori muslimanki i muslimana su pokazali da 52,2 procenata zna da je to pravoslavni blagdan, a 15,5 procenata je odgovorilo da je to katolički blagdan, 0,8 procenata je odgovorilo da je riječ o protestantskom blagdanu, dok je 25,9 procenata izjavilo da ne znaju. Ako se uzme u obzir da je krsna slava porodični blagdan i da većina porodica svetkuje svoga odabranog sveca $\mathrm{i}$ da se na krsnu slavu pozivaju prijatelji i komšije, onda iznenađuje da tek nešto malo više od polovice ispitanih $(3,81$ procenat studenata/ica islamske teologije) su znali odgovor na ovo pitanje. 


\section{Socijalna distanca i otvorenost prema drugima}

U ovom dijelu analize pokazat ćemo koliko su muslimanke i muslimani otvoreni prema drugima, kakva je socijalna distanca prema pripadnicima drugih religija, i koji su najzastupljeniji autostereotipi i heterosterotipi. Socijalna distanca se uglavnom mjeri prema skali koju je kreirao Emory S. Bogardus (1933) čija je svrha utvrditi spremnost ljudi da komuniciraju i surađuju sa većim ili manjim stepenom bliskosti sa drugim pojedincima $i$ grupama koji su etnički, religijski, rasno ili rodno drugačiji od njih. Ako je socijalna distanca veća, to znači da je spremnost na komunikaciju i zajednički život manja, ali i da su stereotipi o drugima vrlo snažni, kao i nepovjerenje i strah, što dodatno potiče udaljavanje i izolaciju. Imajući u vidu da je veliki broj lokalnih zajednica u $\mathrm{BiH}$ nakon rata etnički i religijski homogen i da mladi odrastaju u zatvorenijim sredinama nego što je bio slučaj ranije, onda ne iznenađuje da je socijalna distanca velika.

Prethodna istraživanja u Hrvatskoj i Srbiji pokazuju da što je veći stepen religioznosti i prihvaćanja religijskih načela življenja to je veća socijalna distanca (Vrcan 2001; Joksimović i Kuburić, 2004). Istraživanja provedena u BiH (Turjačanin, 2007; Puhalo, 2009; Abazović, 2012; Pehlić, 2019) pokazuju, također, povezanost razine religijske vrijednosne orijentacije i socijalne distance.

$\mathrm{U}$ ovom istraživanju fokus je bio na pet pitanja iz Bogardusove skale koja su djelomično prilagođena: 1) bračno i porodično srodstvo, 2) bliski prijatelji, 3) prve komšije, 4) saradnici i kolege u poslovnom okruženju, 5) nastavnici, kako bi se ustanovilo koju distancu muslimanke i muslimani imaju prema svojim komšijama, da li su spremni imati ih za bliske prijatelje, sklapati rodbinske odnose, raditi s njima i prihvatiti ih kao nastavnike svoje djece. Pored toga, ponuđena je i skala osobina koje odlikuju pripadnike različitih grupa, na temelju koje se može vidjeti koliko stereotipa muslimanke i muslimani imaju prema drugima, ali i u kojoj mjeri sebe doživljavaju superiornijim u odnosu na druge.

\subsection{Religijska/nacionalna otvorenost prema drugima}

Muslimanke i muslimani su pokazali da najviše poštuju muslimane, zatim katolike, pravoslavne, pa onda jevreje i pripadnike sljedbi/sekti. Zanimljivo da je najveći animozitet izražen prema pripadnicima sljedbi/sekti, jer je riječ o crkvama i zajednicama koje su se odvojile od mainstream učenja i uspostavile zasebne zajednice. Visok animozitet je također izražen prema ateistima/ agnosticima koji su inače $u$ manjini, prema podacima za zadnjeg popisa $u$ 
$\mathrm{BiH}$. Prema jevrejima je, također, izražena velika socijalna distanca, a uzrok tome se može tražiti u globalnim zbivanjima u vezi sa Palestinom i Izraelom.

Tabela 14

\begin{tabular}{llll}
\hline Kao musliman/ka & Poštujem & Nemam ništa protiv & Ne volim ih \\
\hline muslimane & $82,5 \%$ & $6,8 \%$ & $0,4 \%$ \\
\hline katolike & $66,5 \%$ & $24,7 \%$ & $2,4 \%$ \\
\hline pravoslavce & $61,0 \%$ & $26,7 \%$ & $4,8 \%$ \\
\hline jevreje & $51,0 \%$ & $25,9 \%$ & $11,2 \%$ \\
\hline pripadnike sekti & $33,1 \%$ & $30,7 \%$ & $24,3 \%$ \\
\hline ateiste/agnostike & $35,9 \%$ & $33,9 \%$ & 18,3 \\
\hline
\end{tabular}

\section{1) Bračno i porodično srodstvo}

Prvo pitanje iz Bogardusove skale odnosilo se na socijalnu distancu u vezi sa bračnim i porodičnim vezama. Iako je visok procent muslimanki i muslimana odgovorio da poštuju pripadnike drugih religija, njihovi odgovori su ipak drugačiji kada su u pitanju bračni i porodični odnosi. Samo je 0,4 procenta ispitanih odgovorilo da živi s osobom druge vjeroispovijesti i da se dobro slažu, što je očekivano, jer je riječ o studentskoj populaciji. Međutim, 26,3 procenta je odgovorilo da u rodbini imaju osobu druge vjeroispovijesti i da se s njom dobro slažu. Ispitanici pokazuju značajnu socijalnu distancu kada je u pitanju njihova spremnost da stupe u brak sa osobom druge vjeroispovijesti. Veliki broj muslimanki i muslimana nije odgovorio na ovo pitanje, pa se može pretpostaviti da njihov odgovor ne bi bio pozitivan, ali da su možda zbog političke korektnosti izbjegli dati odgovor.

Tabela 15 .

\begin{tabular}{lll}
\hline Za zeta/snahu mogu imati & Da & $\mathrm{Ne}$ \\
\hline muslimane & $63,3 \%$ & 0 \\
\hline katolike & $37,5 \%$ & $20,3 \%$ \\
\hline pravoslavce & $35,1 \%$ & $24,3 \%$ \\
\hline ateiste/agnostike & $29,1 \%$ & $24,3 \%$ \\
\hline
\end{tabular}

2) Bliski prijatelji

Drugo pitanje bilo je usmjereno na to da se vidi kakva je socijalna distanca muslimanki i muslimana u vezi sa prijateljskim vezama sa nemuslimanima. Iz odgovora u naredne dvije tabele jasno se vidi da je preferenca da imaju 
muslimane za kućne i bliske prijatelje, a od nemuslimana na prvom mjestu su katolici. Zanimljivo je da su ateisti/agnostici na dnu ljestvice, s tim da se u izboru bliskog prijatelja na ljestvici izjednačavaju sa pravoslavcima.

Tabela 16.

\begin{tabular}{lll}
\hline Za kućnog prijatelju mogu imati & $\mathrm{Da}$ & $\mathrm{Ne}$ \\
\hline muslimane & $83,7 \%$ & $1,2 \%$ \\
\hline katolike & $60,2 \%$ & $18,3 \%$ \\
\hline pravoslavce & $53,4 \%$ & $24,3 \%$ \\
\hline ateiste/agnostike & $43,0 \%$ & $29,5 \%$ \\
\hline
\end{tabular}

Tabela 17.

\begin{tabular}{lll}
\hline Za bliskog druga/prijatelja mogu imati & Da & Ne \\
\hline muslimane & $83,7 \%$ & $1,2 \%$ \\
\hline katolike & $60,2 \%$ & $18,3 \%$ \\
\hline pravoslavce & $53,4 \%$ & $24,3 \%$ \\
\hline ateiste/agnostike & $53,0 \%$ & $22,3 \%$ \\
\hline
\end{tabular}

\section{3) Prve komšije}

Komšiluk je u $\mathrm{BiH}$ i na Balkanu općenito njegovan stoljećima, međutim ovaj pojam je ambivalentan, jer se s jedne strane glorificira i idealizira, a s druge minimizira kao konstrukt koji nema utemeljenje u stvarnosti. Istraživači koji su analizirali ovo pitanje na Balkanu (Jansen et al. 2016) zaključuju da su pripadanje i socijalnost prilično fluidne forme i da se mijenjaju prema društveno-političkim i drugim promjenama u ovim društvima. Poznata studija Biti Musliman na bosanski način (Bringa, 1995), također govori o važnosti komšiluka koji nije ograničen samo na komšije iste nacionalne i religijske grupe, ali koji treba razumijevati kao izraz različitih formi lojalnosti i reciprociteta. Cornelia Sorabji (1994) u svom istraživanju pokazuje da je pojam komšiluka bio usko povezan sa pojmom narod koji je mnogo kompleksniji i višeznačniji od pojma nacionalnost. Primjerice, izjava sa početka ovog poglavlja: "Ovdje su narodi i ljudi uvijek živjeli zajedno, slavili praznike i poštovali jedni druge", također svjedoči u prilog povezanost pojma komšiluk sa pojmom narod. Pojam komšiluk je turcizam i označava čitav niz socijalnih konvencija kao što su druženje, kahvenisanje, obilježavanje praznika i pomaganje (Spahić Šiljak, 2015, 347) 
U ovom dijelu istraživanja donosimo odgovore muslimanki i muslimana o tome koliko su spremni živjeti zajedno u komšiluku sa pripadnicima drugih religija i tradicija. Muslimanke i muslimani u ovoj grupi su se u najvećoj mjeri izjasnili da bi željeli da im komšije budu pripadnici njihove religijske tradicije. Nakon toga su spremni prihvatiti katolike za komšije, pa pravoslavce, a ateisti su na zadnjem mjestu. Iako istraživanje nije detaljno propitivalo razloge, ipak je znakovito da su ateisti i agnostici zadnji na ljestvici i da vjernici preferiraju da im prve komšije budu vjernici. Razlog zašto muslimani preferiraju da im prve komšije budu muslimani treba tražiti i u ratnim dešavanjima od 1992-1995 zbog kojih se većina i etnički i religijski više homogenizira.

Tabela 18 .

\begin{tabular}{lll}
\hline Za komšjiu mogu imati & $\mathrm{Da}$ & $\mathrm{Ne}$ \\
\hline muslimane & $82,9 \%$ & $1,2 \%$ \\
\hline katolike & $69,3 \%$ & $10,8 \%$ \\
\hline pravoslavce & $65,7 \%$ & $14,7 \%$ \\
\hline ateiste/agnostike & $53,0 \%$ & $21,5 \%$ \\
\hline
\end{tabular}

4) Saradnici i kolege u radnom okruženju

Radno okruženje ne pripada intimi porodice, ali je vrlo važno za svaku osobu, jer on/a provode veliki dio svog vremena na radnom mjestu i ako imaju priliku biraju s kakvim osobama će dijeliti radni prostor, a posebno kakvu osobu će prihvatiti za šefa. Istraživanja (Nix, 1993, 6) pokazuju da se vjernici najviše socijaliziraju sa vjernicima svoje religijske tradicije, kao što pokazuje i ovo istraživanje provedeno u BiH. Međutim, na tu socijalizaciju utječu i drugi faktori, kao što su etnicitet, rasa, kultura i slično. Tako su crkve i religijske organizacije rasno, etnički i klasno organizirane. Na primjer, muslimani iz $\mathrm{BiH}$ se radije socijaliziraju sa muslimanima iz istog govornog područja i kulture, pa zbog toga u dijaspori grade bosanske džamije koje su i mjesta na kojima čuvaju svog jezik i kulturne posebnosti.

Slično je i sa radnim okruženjem, pa se oni koji se deklariraju kao vjernici odlučuju da se i u radnom okruženju više socijaliziraju sa vjernicima ako imaju mogućnost za to. Muslimanke i muslimani u ovom istraživanju su to i potvrdili i u najvećem broju se izjasnili da bi za šefa najviše voljeli imati muslimana. 
Tabela 19.

\begin{tabular}{lll}
\hline Za šefa mogu imati & Da & Ne \\
\hline muslimane & $80,5 \%$ & $1,6 \%$ \\
\hline katolike & $53,8 \%$ & $21,9 \%$ \\
\hline pravoslavce & $49,0 \%$ & $27,1 \%$ \\
\hline ateiste/agnostike & $44,2 \%$ & $26,3 \%$ \\
\hline
\end{tabular}

U sličnim procentima muslimanke i muslimani su odgovorili i na pitanje $u$ vezi sa poslovnim partnerom koji je nemusliman. Nema značajnije statističke razlike i najveći broj bi se odlučio da za poslovnog partnera odabere muslimana, što znači da se i povjerenje u poslovnim odnosima mjeri religijskom pripadnošću.

\section{5) Nastavnici moje djece}

Jedna od varijabli odnosila sa na povjerenje ispitanika da za nastavnika svoje djece biraju nekoga ko nije pripadnik njihove religije. Većina je ponovo odabrala muslimane. Podučavanje i općenito obrazovanje imaju veliku ulogu u sekundarnoj socijalizaciji, jer utječu na kognitivni i moralni razvoj ličnosti, ne samo preko sadržaja gradiva koje nastavnici predaju, već i preko vrjednosnih normi koje nastavnik pokazuje u procesu podučavanja. Istraživanja potvrđuju da nastavnik ima ulogu moralnog autoriteta i da su neodvojivi njegovo/njeno znanje i vještine od njegovih/njenih uvjerenja i vjerovanja. (Pantić 2011, 165-178) Sljedeća tabela pokazuje da muslimanke i muslimani preferiraju muslimane kao nastavnike svoje djece, a onda katolike i pravoslavce i tek na zadnjem mjestu su ateisti i agnostici.

Tabela 20.

\begin{tabular}{lll}
\hline Za nastavnika moje djece prihvaćam & Da & $\mathrm{Ne}$ \\
\hline muslimane & $83,3 \%$ & $0,8 \%$ \\
\hline katolike & $57,8 \%$ & $19,5 \%$ \\
\hline pravoslavce & $53,8 \%$ & $23,1 \%$ \\
\hline ateiste/agnostike & $43,8 \%$ & $28,7 \%$ \\
\hline
\end{tabular}

\subsection{Auostereotipi muslimana i heterosterotpi prema drugima}

U analizi podataka o socijalnoj distanci koju muslimanke i muslimanke pokazuju prema drugima, vidljivo je da su autostereotipi o vlastitoj religijskoj 
grupi u najvećoj mjeri pozitivni. Među osobinama koje su im ponuđene u skali, muslimanke i muslimani su pripadnike svoje religijske tradicije ocijenili kao: tolerantne, religiozne, duhovite, inteligentne, snalažljive, privržene porodici i vrijedne, a u manjem procentu kao materijaliste, impulzivne, ekstremne nacionaliste, lukave, ratoborne, nepristupačne i praznovjerne.

Ako pogledamo rezultate sličnih istraživanja koja su provedena sa grupama srednjoškolaca (Turjačanin 2007), ili istraživanje koje je obuhvatilo i mlade i stariju populaciju (Puhalo 2009), vidljiv je sličan obrazac u navođenju pozitivnih autostereotipa za vlastitu grupu.

Tabela 21 .

\begin{tabular}{llllll}
\hline $\begin{array}{l}\text { Pozitivni autosterotipi i } \\
\text { heterostereotipi (muslimani) }\end{array}$ & Muslimani & Katolici & Pravoslavci & Jevreji & $\begin{array}{l}\text { Ateisti/ } \\
\text { Agnostici }\end{array}$ \\
\hline privrženi porodici & $46,6 \%$ & $4,4 \%$ & $3,2 \%$ & $5,5 \%$ & $0,8 \%$ \\
\hline vrijedni & 44,6 & $4,0 \%$ & $2,4 \%$ & $4,4 \%$ & $0,4 \%$ \\
\hline inteligentni & $41,4 \%$ & $4,4 \%$ & $2,8 \%$ & $6,0 \%$ & $5,0 \%$ \\
\hline veoma religiozni & $29,1 \%$ & $4,4 \%$ & $3,6 \%$ & $2,8 \%$ & $2,2 \%$ \\
\hline snalažljivi & $25,8 \%$ & $4,8 \%$ & $3,2 \%$ & $4,8 \%$ & $3,2 \%$ \\
\hline tolerantni & $25,5 \%$ & $4,0 \%$ & $3,2 \%$ & $4,8 \%$ & $2,8 \%$ \\
\hline duhoviti & $22,3 \%$ & $5,6 \%$ & $3,6 \%$ & $4,4 \%$ & $3,2 \%$ \\
\hline naivni & $17,1 \%$ & $2,4 \%$ & $2,0 \%$ & $3,2 \%$ & $8,0 \%$ \\
\hline muzikalni & $9,6 \%$ & $10,4 \%$ & $7,2 \%$ & $4,0 \%$ & $4,8 \%$ \\
\hline
\end{tabular}

Muslimanke i muslimani sebe doživljavaju prije svega kao privržene porodici, zatim kao vrijedne i inteligentne osobe, kao religiozne i tolerantne, ali i duhovite. Jedino za karakteristiku muzikalnosti su dali prednost katolicima $i$ to je vjerovatno zbog toga što je katolički obred praćen instrumentalnom i vokalnom muzikom. Zanimljivo je u kojoj mjeri pozitivni autostereotipi pokazuju da ne postoji kritički odmak ili barem pokušaj da se navedene karakteristike u višem procentu pripišu i drugima.

Prema Teroriji društvenog identiteta (Tajfel i Turner 1986), pojedinci integriraju općeprihvaćene karakteristike grupe kojoj pripadaju, a koje ih predstavljaju na pozitivan način. Što je izražajnija identifikacija sa grupom, pripadnici te grupe usvajaju karakteristike te grupe kao svoje iako samo ne moraju biti takvi (Latrofa et.al. 2012). Autostereotipi se povećavaju onda kada se grupa osjeća ugroženom ili kada dio je identiteta te grupe negiran, kao što je slučaj sa Bošnjacima u post-ratnom kontekstu BiH čiji se identitet 
ili dijelovi identiteta osporavaju - npr. pitanje bosanskog jezika. Slična je situacija i sa onima koji su ustavno smješteni u kategoriju Ostalih i ne mogu ostvarivati temeljna građanska i politička prava jednako kao i drugi građani koji su većina.

Pozitivni heterostereotipi prema drugima pokazuju da muslimani imaju manju socijalnu distancu prema katolicima i jevrejima u odnosu na pravoslavne i ateiste/agnostike. Različiti su načini na koji Bošnjaci odnosno muslimani formiraju svoje stavove o drugima, i ono što je Srđan Puhalo (2009) potvrdio u svom istraživanu, je da rat i ono što se događalo i događa nakon rata u najvećoj mjeri određuje odnos prema drugoj grupi. Bošnjaci tako imaju veću socijalnu distancu prema Srbima nego prema Hrvatima (Ibid.), a u ovom istraživanju muslimani imaju veću socijalnu distancu prema pravoslavcima.

Najizražajniji heterostereotipi prema komšijama su sljedeći: pravoslavci su ratoborni, ekstremni nacionalisti, lukavi i primitivni; jevreji su ekstremni nacionalisti, škrti, nepristupačni, lukavi i praznovjerni; katolici su koristoljubivi, lukavi, prevrtljivi, konzervativni i ekstremni nacionalisti; ateisti i agnostici su neobrazovani, praznovjerni, nepristupačni, ekstremni nacionalisti i primitivni.

Tabela 22.

\begin{tabular}{llllll}
\hline $\begin{array}{l}\text { Negativni autosterotipi i } \\
\text { heterostereotipi muslimani }\end{array}$ & Muslimani & Katolici & Pravoslavci & Jevreji & $\begin{array}{l}\text { Ateisti/ } \\
\text { Agnostici }\end{array}$ \\
\hline prevrtljivi & 13,9 & $4,0 \%$ & $6,2 \%$ & $4,4 \%$ & $2,8 \%$ \\
\hline lukavi & $10,0 \%$ & $5,6 \%$ & $12,0 \%$ & $7,6 \%$ & $1,6 \%$ \\
\hline ratoborni & $10,8 \%$ & $2,8 \%$ & $15,5 \%$ & $4,0 \%$ & $2,4 \%$ \\
\hline konzervativni & $9,6 \%$ & $5,2 \%$ & $6,0 \%$ & $6,0 \%$ & $4,0 \%$ \\
\hline praznovjerni & $9,2 \%$ & $4,4 \%$ & $3,6 \%$ & $8,0 \%$ & $9,2 \%$ \\
\hline koristoljubivi & $6,8 \%$ & $7,2 \%$ & $6,4 \%$ & $7,6 \%$ & $4,4 \%$ \\
\hline nepristupačni & $6,4 \%$ & $3,2 \%$ & $6,0 \%$ & $9,2 \%$ & $9,2 \%$ \\
\hline škrti & $5,6 \%$ & $3,2 \%$ & $6,8 \%$ & $10,4 \%$ & $2,4 \%$ \\
\hline primitivni & $5,2 \%$ & $1,6 \%$ & $7,2 \%$ & $7,6 \%$ & $7,2 \%$ \\
\hline neobrazovani & $3,6 \%$ & $0,4 \%$ & $4,8 \%$ & $6,4 \%$ & $12,7 \%$ \\
\hline ekstremni nacionalisti & $2,8 \%$ & $4,4 \%$ & $10,4 \%$ & $10,0 \%$ & $8,0 \%$ \\
\hline
\end{tabular}

Kako se vidi iz ove tabele, muslimani imaju veliki broj negativnih heterostereotipa prema drugima, ali u većem procentu navode negativne autostereotipe: njih 13,9 procenata kaže da su muslimani prevrtljivi, 10,0 procenata misli da su lukavi, 10,8 procenata da su ratoborni, 9,6 procenata da su konzer- 
vativni, a 9,2 procenta da su praznovjerni. Od svih negativnih autostereotipa, za sebe muslimani misle da su najmanje ekstremni nacionalisti u odnosu na pravoslavce, katolike, jevreje, pa i ateiste i agnostike i najmanje neobrazovani, primitivni, škrti i nepristupačni u odnosu na pravoslavce, jevreje, ateiste i agnostike.

Ako se uz sve navedene podatke u ovoj analizi doda i to da se 75,7 procenta muslimanki i muslimana potpuno slažu da je islam jedina istinita vjera, a 5,6 procenata da se djelomično, onda je to ogromna većina mladih koji imaju eksluzivistički stav o svojoj religiji. Ako usporedimo to sa odgovorima katolika i pravoslavaca, onda je vidljivo da oni u manjoj mjeri izražavaju eksluzivitet svoje religijske tradicije. Kršćanstvo je jedina istinita vjera potpuno se slaže 58,9 katolika, 8,9 procenata se djelomično slažu, dok se samo 28,2 procenta pravoslavnih potpuno slažu da je pravoslavlje jedina istinita vjera, a 16,9 procenata se djelomično slaže.

\section{Zaključak}

Istraživanje pod nazivom "Koliko se poznajemo" pokazalo da je mladi koju su se dekalirali kao muslimanke i muslimani (94,8 procenata) u mnogo manjem procentu prakticiraju islam, odnosno vrlo mali broj, odlazi u džamiju na molitvu: 16,7 procenata posjećuje džamiju više od jednom sedmično, a 19,9 jednom sedmično. Preko ideološke, obredne i intelektualne dimenzije religioznosti ustanovili smo da većina ispitanika i ispitanica dobro poznaje osnovna načela islama i strukturu Islamske zajednice, ali da je njihovo znanje na vrlo niskoj razini kada je u pitanju povijest islama, sadržaj svetog teksta Kur'ana i obilježavanje blagdana.

Socijalna distanca prema pripadnicima drugih religijskih tradicija, prije svega prema katolicima, pravoslavcima i jevrejima, a onda i prema onima koji imaju nereligijski svjetonazor, prilično je velika. Iako muslimani i muslimanke solidno poznaju strukturu Katoličke crkve a nešto manje strukturu Pravoslavne crkve i Jevrejske zajednice, vrlo malo su upućeni u osnovna načela vjerovanja: sveti sakramenti, dekalog, sadržaj Biblije, kao i svetkovanje blagdana. Mnogo više katolici i pravoslavci poznaju islam, nego što muslimani poznaju katoličanstvo i pravoslavlje.

Muslimanke i muslimani su se izjasnili da najviše poštuju muslimane, zatim katolike, pravoslavne, pa onda jevreje, pripadnike sljedbi/sekti i ateiste/ agnostike. Najveći animozitet i distancu su pokazali prema jevrejima, pripadnicima sljedbi/sekti i ateistima/agnosticima koji su inače manjina u $\mathrm{BiH}$. 
Kada uz sve ovo doda, da bi muslimanke i muslimani najviše voljeli da za prijatelje, prve komšije, rodbinu, radne i poslovne kolege, kao i nastavnike svoje djece imaju muslimane onda je jasno da se mladi ispitanici koji su uglavnom socijalizirani u homogenim etničkim i religijskim zajednicama najsigurnije osjećaju sa muslimanima. Ipak, ohrabruje to što je veliki procent onih koji su se izjasnili da bi prihvatili katolike pravoslavce, pa onda jevreje i ateiste kao prijatelje, komšije, poslovne partnere, rodbinu i nastavnike za svoju djecu, Zanimjivo je da muslimani imaju najmanju distancu prema katolicima, i da su katolici prvi na ljestvici koje bi muslimani birali za prijatelje, komšije, poslovne partnere i nastavnike svoje djece. Kada se sumiraju negativni heterostereotipi koje muslimani imaju prema drugim, oni su također $\mathrm{u}$ najmanjem procentu izraženi prema katolicima.

Poštovanje i deklarativna spremnost na dijalog, bez boljeg poznavanja religije svojih komšija i eliminiranje negativnih heterostereotipa koje imaju prema njima, nisu znak istinske opredjeljenosti za kulturu mira. Uglavnom je to znak pasivne tolerancije, a to nije dovoljno da se kultivira zajednički život u različitosti. Pasivna tolerancija, priznaje razlike, ali ih ne prihvaća i ne cijeni kao legitiman i potreban izvor izgradnje mira i progresa u jednom društvu. Dokle god je to tako, život jednih pored drugih uz deklarativno prihvaćanje razlika, neće doprinijeti razgrađivanju zidova stereotipa i predrasuda, već će ih učvršćivati, a zidovi i podjele nisu nikada izrodili ništa dobro za građanke i građane jedne zajednice, a posebno ne za one koji su manjina.

\section{Literatura:}

Abazović, D. (2012). Bosanskohercegovački muslimani između sekularizacije i desekularizacije. Zagreb-Sarajevo: Synopsis.

Abdulcadir, J; Alexander S; Dubuc, E; Pallitto, C; Petignat, P; Say, L. (2017). Female genital mutilation/cutting: sharing data and experiences to accelerate eradication and improve care. Reproductive Health 14(Suppl 1), 96.

Aboud, F. E. (1988). Children and Prejudice, Oxford: Basil Blackwell.

Appleby, S. (2000). The Ambivalence of the Sacred. Religion, Violence and Reconciliation. Maryland: Rowman \& Littlefield.

Bennett, J.M. (2013). Basic Concepts of Intercultural communication: paradigms, principles and practices, 2. izd. Boston-London: Nicholas Brealey Publishing Company.

Bloch, M. (1992). Prey into Hunder. Cambridge: Cambridge University Press.

Bogardus, E.S. (1933). A Social Distance Scale. Sociology and Social Research. No 17. $265-271$.

Bringa, T. (1995). Biti musliman na bosanski način: identitet i zajednica u jednom srednjobosanskom selu. Sarajevo: Šahinpašić.

Bougarel, H. (2017). Islam and Nationhood in Bosnia and Herzegovina. Surviving Empires. prev. na engl. Cristopher Mobley. London-Oxford-New York: Bloomsbury Publishing. 
Bourdieu, P. (1987). Legitimation and Structured Interests in Weber's Sociology of Religion, u Max Weber, (Ur.) Rationality and Modernity, S. Lash and S. Whimster, London: Allen \& Unwin, 119-136.

Cvitković, I. (2002). Religije suvremenog svijeta. Sarajevo: DES.

Cvitković, I. (2007). Sociologija religije. 4. izdanje, Sarajevo: DES.

Cvitković, I. (2014). Sociologija obreda. Sarajevo: Nacionalna i univerzitetska biblioteka Bosne i Hercegovine.

Da-Don, R.K. (2004). Židovstvo. Život, teologija, filozofija. Zagreb: Profil International d.o.o.

Davie, G. (1994). Religion in Britain Since 1945: Believing Without Belonging (Making Contemporary Britain). New Jersey: John Wiley \&Sons.

Davie, G. (2012). From Believing without Belongins to Vicarious Religion. Understanding the Patterns of Religion in Modern Europe. u D. Pollack i D. V. A. Olson (Ur.), The role of Religion in Modern societies. Routledge Press.

Durkheim, E. (1954). The Elementary Forms of The Religious Life. London: Allen\&Unwin.

Flere, S. (2007). Konsekventnost religioznosti bosanskih muslimana. Islam at the Balkans in the past, today and in the future. Niš: Junir.

France, R. (1987). Biblija, u Religije svijeta. Enciklopedijski priručnik. Zagreb: Kršćanska sadašnjost.

Hrvatska enciklopedija, Kalendar, https://enciklopedija.hr/natuknica.aspx?id=29893, Pristupljeno, 14.10.2020.

Hrvatska enciklopedija, Pravoslavne crkve, https://enciklopedija.hr/natuknica.aspx?id=50016, Pristupljeno, 14.10.2020.

Imamović, M. (2003). Bošnjački etnos: identitet i ime. Prilozi, br. 32, Sarajevo: Institut za istoriju Sarajevo, 315-329.

Institucija uleme. Islamska zajednica u Bosni i Hercegovini: https://www.islamskazajednica. ba/institucija-reisu-1-uleme, Pristupljeno 22.10.2020.

Islamska zajednica BiH. Savjet Muftijstva zeničkog donio Odluku o organiziranju džumanamaza za žene (2019) https://www.islamskazajednica.ba/muftijstva-s/vijesti-izmuftijstava/28312-savjet-muftijstva-zenickog-donio-odluku-o-organiziranju-dzumanamaza-za-zene, 14.11.2019. Pristupljeno 22.10.2020.

Jansen, S.; Č. Brković; V. Čelebičić, (Ur.), (2016). Negotiating social relations in Bosnia and Herzegovina: Semiperipheral entanglements. New York: Routledge.

Jevrejska opština Sarajevo.https://www.jews.ba/Menu/4/JC-Sarajevo, pristupljeno 12.10.2020

Joksimović, S., \& Kuburić. Z. (2004). Mladi i vjerska tolerancija, Religija i tolerancija, br. 1. 17-30, Novi Sad: Centar za empirijska istraživanja religije.

Karić, E. (2005). Kako tumačiti Kur'an, Sarajevo: Tugra.

Kristić, A. (2009). Etika - dobročinstvo i religije, u Spahić Šiljak i Abazović Dino (Ur.) Monoteističko troglasje. Uvod u Judaizam, kršćanstvo i islam, Sarajevo: Rabic - IMICCIPS-TPO Fondacija.

Kuburić, Z. i Kuburić Borović, M. (2009). Revitalization of Religion in the Balkans, u: 31.Danijela Gavrilović (ur.) Revitalization of Religion: Theoretical and Comparative Approaches. Niš: Yugoslav Society for Scientific Study of Religion.

Latrofa, M.; Vaes, J; Cadinu, M. (2012). Self-Stereotyping: The Central Role of an Ingroup Threatening Identity. The Journal of Social Psychology. 152 (1), 92-111.

Majstorović, D. i Turjačanin, V. (2013). Youth Ethnic and National Identity in Bosnia and Herzegovina. Social Science Approaches, London: Palgrave McMilan. 
Markešić, I. (2010). Od religijskog do nacionalnog identiteta i natrag (na primjeru BiH). Društvena istraživanja, 19, br.3/2010. Zagreb: Institut društvenih znanosti Ivo Pilar.

Mitteaur, M. (2008). Religije u Jugoistočnoj Europi: historijskoantropološki pristup: historijskoantropološki pristup // Migracijske i etničke teme, 24. 1-2; 7-30.

Nissenbaum, S. (1997). The Battle for Christmas: Social and Cultural History of our Most Cherished Holiday. New York: Vintage Books.

Nix, J. (1993). Assessing the existence of social distance and factors that affect its magnitude at a southern university, neobjavljena doktorska teza, dostupna na: https://www. academia.edu/652936/Assessing_the_existence_of_social_distance_and_factors that affect_its_magnitude_at_a_southern_university Pristupljeno 05.10.2020.

Pantić, N. (2011). Teacher Competence as a Basis for Teacher Education: Comparing Views of Teachers and Teacher Educators in Five Western Balkan Countries. Comparative Education Review 55(2):165-188.

Pašalić Kreso, A. (2016). Pravimo iskorake učeći jedni od drugih, u A. Pašalić Kreso (Ur.) Zbornik radova odsjeka za pedagogiju. Ka novim iskoracima u odgoju i obrazovanju. godina 1. broj 1., 19.

Pehlić, I. (2019). Socijalna distanca među mladima. Sarajevo: Centar za napredne studije, https://iiit.org/wp-content/uploads/Socijalna-distanca-medju-mladima_KB-print.pdf, Pristupljeno, 08.10.2020.

PEW Research: Religious beliefs and practices. (2017):

https://www.pewforum.org/2017/07/26/religious-beliefs-and-practices.Pristupljeno, 02.10 .2020

PEW Research: Women and men about equally likely to believe in heaven, hell and angels. (2016). https://www.pewforum.org/2016/03/22/women-and-men-about-equally-likelyto-believe-in-heaven-hell-and-angel, Pristupljeno, 02.10.2020.

Piaget, J. i Weil, A.M. The development in the child of the idea of homeland and of foreign relationships, u Smith, L. (Ur.), Sociological Studies, London: Routledge, 248-75.

Pippa, N. i Inglehart, R. (2011). Sacred and Secular: Religion and Politics Worldwide. 2.izdanje, New York: Cambridge University Press.

Pravoslavlje zapadnog obreda, https://orthodoxhr.wordpress.com/2018/07/25/pravoslavljezapadnog-obreda/, Pristupljeno, 16.10.2020.

Puhalo, S. (2009). Etnička distanca i (auto)stereotipi građana Bosne i Hercegovine. Sarajevo: Friedrich Ebert Stiftung.

Sorabji, C. (1994). Mixed motives: Islam, nationalism and mevluds in an unstable Yugoslavia. u Fawzi El-Sohl, C. i Mabro, J. (Ur.). Muslim women's choices: Religious belief and social reality, 109-127. Providence, RI: Berg.

Spahić Šiljak i Abazović D. (Ur.). Monoteističko troglasje. Uvod u Judaizam, kršćanstvo i islam, Sarajevo: Rabic - IMIC-CIPS-TPO Fondacija.

Spahić Šiljak, Z. (2007). Žene, religija i politika. Analiza utjecaja interpretativnog religijskog naslijeđa, judaizma, kršćanstva i islama na angažman žene u javnom životu i politici. Sarajevo: IMIC-CIPS-TPO.

Spahić Šiljak, Z. (Ur.). (2012). Propitivanje ženskih, feminističkih i musimanskih identiteta. Post-socijalistički konteksti u Bosni i Hercegovini i na Kosovu. Sarajevo: Centar za interdiscplinarne postdiplomske studije Univerziteta u Sarajevu.

Spahić Šiljak, Z. (2015). Merhametli Peace is Woman's Peace: Religioius and Cultural Practices of Compassion and Neighbourlines in Bosnia and Herzegovina, u Saikia Yasmin and 
Haines Chad (Ur.) Women and Peace in the Islamic World: Gender Agency and Influence. London: I.B. Tauris.

Steffler, A. W. (2002). Symbols of the Christian Faith. Cambridge: William Eerdmans Publishing.

Šećibović, R. (1995). Uvod u opštu geografiju religije. Novi Sad: Promotej.

Šušnjić, Đ. (1998). Religija I, Beograd:Čigoja štampa.

Tajfel, H. i Turner, J.C . (1986). The social identity theory of intergroup behavior. Chicago: Nelson-Hall.

Turjačanin, V. (2007). Psihosocijalni prostor i etnički odnosi mladih. Banja Luka: Filozofski fakultet.

Turner, J.C; Oakes, P. J.; Haslam, S. A.; McGarty, C. (1994). Self and collective: Cognition and social context. Personality and Social Psychology Bulletin. 20 (5), 454-463.

Zakon o slobodi vjere i pravnom položaju crkava i vjerskih zajednica u Bosni i Hercegovini ("Službeni glasnik BiH", broj 5/04).

Vrcan, S. (2001). Vjera u vrtlozima tranzicije, Split: Dalmatinska akcija.

Vukomanović, M. (2008). Homo Viator. Religija i novo doba. Beograd: Čigoja štampa.

Wolf, M. (2015). Allah- kršćanski odgovor. Rijeka-Sarajevo: Ex Libris, Synopsis. 